\title{
Estimation of $\mathrm{NO}_{\mathrm{x}}$ emissions from Delhi using Car MAX-DOAS observations and comparison with OMI satellite data
}

\author{
R. Shaiganfar ${ }^{1}$, S. Beirle ${ }^{1}$, M. Sharma ${ }^{2}$, A. Chauhan ${ }^{2}$, R. P. Singh ${ }^{2,3}$, and T. Wagner ${ }^{1}$ \\ ${ }^{1}$ Max-Planck-Institute for Chemistry, Mainz, Germany \\ ${ }^{2}$ Research and Technology Development Centre, Sharda University, Greater Noida, India \\ ${ }^{3}$ School of Earth and Environmental Sciences, Schmid College of Science, Chapman University, Orange 92866, USA
}

Received: 20 April 2011 - Published in Atmos. Chem. Phys. Discuss.: 5 July 2011

Revised: 17 October 2011 - Accepted: 23 October 2011 - Published: 3 November 2011

\begin{abstract}
We present the first Multi-Axis-(MAX-) DOAS observations in India performed during April 2010 and January 2011 in Delhi and nearby regions. The MAX-DOAS instrument was mounted on a car roof, which allowed us to perform measurements along individual driving routes. From car MAX-DOAS observations along closed circles around Delhi, together with information on wind speed and direction, the $\mathrm{NO}_{\mathrm{x}}$ emissions from the greater Delhi area were determined: our estimate of $4.4 \times 10^{25}$ molecules s $^{-1}$ is found to be slightly lower than the corresponding emission estimates using the EDGAR emission inventory and substantially smaller compared to a recent study by Gurjar et al. (2004). We also determined $\mathrm{NO}_{\mathrm{x}}$ emissions from Delhi using OMI satellite observations on the same days. These emissions are slightly smaller than those from the car MAXDOAS measurements. Finally the car MAX-DOAS observations were also used for the validation of simultaneous OMI satellite measurements of the tropospheric $\mathrm{NO}_{2} \mathrm{VCD}$ and found a good agreement of the spatial patterns. Concerning the absolute values, OMI data are, on average, higher than the car MAX-DOAS observations close to strong emission sources, and vice versa over less polluted regions. Our results indicate that $\mathrm{OMI} \mathrm{NO}_{2}$ VCDs are biased low over strongly polluted regions, probably caused by inadequate apriori profiles used in the OMI satellite retrieval.
\end{abstract}

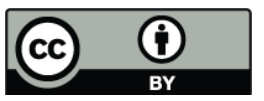

Correspondence to: R. Shaiganfar (r.shaiganfar@mpic.de)

\section{Introduction}

Delhi, home of 19 million people, second largest metropolitan city (http://www.indiaonlinepages.com/population/ delhi-population.html) is located in the Indo-Gangetic plains in India. The growing population and human activities increase the atmospheric pollution which is e.g. the cause of the dense fog, smog and haze during winter season (December and January) every year (Singh et al., 2004, 2005; Ramanathan and Ramana, 2005; Ramanathan et al., 2005; Gautam et al., 2007). In the years 2005 and 2006, about 4.8 million vehicles were in operation in Delhi.

In the last three decades the atmospheric trace gas and aerosol loading has increased in the Indo-Gangetic plains due to intense urbanization, anthropogenic activities, industrial growth and energy demand. Especially in the northern part of India, the pollutants swing in the Indo-Gangetic basin depending upon the meteorological conditions. The sources of atmospheric pollutants are localized and heterogeneous and depended on season (Gurjar et al., 2004; Goyal et al., 2006; Lal, 2007).

The measurements of atmospheric pollutants are important for monitoring the air quality and for understanding the radiative forcing and its impact on climate (Ravishankara et al., 2004; Seinfeld and Pandis, 2006). Currently, still large uncertainties exist with respect to the total emissions of pollutants and their impact on local, regional, and possibly also global scale. The corresponding uncertainties are especially large for many megacities.

In this study, we present top-down emission estimates for nitrogen oxides $\left(\mathrm{NO}_{\mathrm{x}}=\mathrm{NO}+\mathrm{NO}_{2}\right)$ for Delhi from car MAX-DOAS observations. Nitrogen oxides are formed in combustion processes (e.g. from vehicles, and power plants);

Published by Copernicus Publications on behalf of the European Geosciences Union. 
they are toxic (Elsayed, 1994; World Health Organization, 2003) and also involved in important photochemical processes. Together with the emissions of volatile organic compounds, they control tropospheric ozone chemistry and oxidising capacity (Jacob, 1999; Seinfeld and Pandis, 2006).

We use Multi-Axis-Differential Optical Absorption Spectroscopy (MAX-DOAS) measurements (Hönninger et al., 2002; Van Roozendael et al., 2003; Wittrock et al., 2004; Wagner et al., 2004; Brinksma et al., 2008 and references therein) to quantify the $\mathrm{NO}_{\mathrm{x}}$ emissions of Delhi. The MAXDOAS instrument was mounted on a car roof, and continuous measurements were performed on closed driving routes around the city center on three days during April 2010 and one day in January 2011. In combination with wind data, the total emissions from the encircled area can be determined (Johansson et al., 2008, 2009; Rivera et al., 2009; Ibrahim et al., 2010; Wagner et al., 2010).

In addition to the quantification of the $\mathrm{NO}_{\mathrm{x}}$ emissions, the MAX-DOAS results are also used for the validation of satellite observations of the tropospheric $\mathrm{NO}_{2} \mathrm{VCD}$. Car MAX-DOAS observations yield valuable information about the horizontal heterogeneity of the $\mathrm{NO}_{2}$ distribution, which can not be resolved by the satellite observations, making them advantageous compared to validation with MAXDOAS measurements at fixed locations.

The paper is organized as follows: in Sect. 2, we give details of the instrument, the measurement campaign and the retrieval of the tropospheric $\mathrm{NO}_{2} \mathrm{VCD}$. Section 3 presents the determination of the $\mathrm{NO}_{\mathrm{x}}$ emissions of Delhi and comparison with the EDGAR emission inventory. In Sect. 4, the MAX-DOAS tropospheric $\mathrm{NO}_{2}$ VCDs are compared to simultaneous satellite observations from the Ozone Monitoring Instrument (OMI).

\section{MAX-DOAS observations and data analysis}

\subsection{Car MAX-DOAS instrument}

The Mini-MAX-DOAS instrument is a fully automated, light weighted spectrometer $(13 \mathrm{~cm} \times 19 \mathrm{~cm} \times 14 \mathrm{~cm})$ designed for the spectral analysis of scattered sunlight (Bobrowski et al., 2003). It consists of a sealed aluminium box containing the entrance optics, a fibre coupled spectrograph and the controlling electronics. A stepper motor mounted outside the box rotates the whole instrument to control the elevation of the viewing angle (angle between the horizontal and the viewing direction). The entrance optics consists of a quartz lens of focal length $f=40 \mathrm{~mm}$ coupled to a quartz fibre bundle which leads the collected light into the spectrograph (field of view is $\sim 1.2^{\circ}$ ). The light is dispersed by a crossed CzernyTurner spectrometer (USB2000+, Ocean Optics Inc.) with a spectral resolution of $0.7 \mathrm{~nm}$ over a spectral range from 320 $460 \mathrm{~nm}$. A one-dimensional CCD (Sony ILX511, 2048 individual pixels) is used as detector. The measurements were controlled from a laptop using the DOASIS software (Kraus, 2006).

\subsection{Overview on measurements around Delhi}

For the mobile observations measurements around Delhi, the Mini-MAX-DOAS instrument was mounted on the roof top of a car with the telescope mounted parallel to the driving direction, pointing backward (April 2010)/forward (January 2011). The measurements started from Greater Noida to Delhi and around Delhi; the routes are shown in Fig. 1 for all the four days (13, 14, and 15 April 2010 and 15 January 2011).

The sequence of elevation angles was chosen to: $1 \times 90^{\circ}$, $5 \times 22^{\circ}, 1 \times 45^{\circ}, 5 \times 22^{\circ}$ and the duration of an individual measurement was about $60 \mathrm{~s}$. For the measurements on 15 January 2011 , an elevation angle of $30^{\circ}$ was set up instead of $22^{\circ}$ during April 2010. The temperature setpoint of the mini MAX-DOAS was $15^{\circ} \mathrm{C}$ in April and $5^{\circ} \mathrm{C}$ in January. A handy GPS was used to track the coordinates of the route along which the observations were made.

All the three days in April 2010 were cloud-free, the aerosol optical depth derived from MODIS satellite was found in the range of $0.2-0.5$ at $550 \mathrm{~nm}$ (data taken from the AERONET data synergy tool, http://aeronet.gsfc.nasa. gov/cgi-bin/bamgomas_interactive). On 15 January 2011, the AOD was found to be only 0.1 in the afternoon. During the start of the measurements at 11 am the AOD may be higher, but we do not have any estimate due to non availability of MODIS aerosol data. The range of AOD is consistent with those measured by AERONET in Delhi for January and April 2009 (see http://aeronet.gsfc.nasa.gov/). They are also consistent with those reported in the study of Satheesh et al. (2011) for the city of Bangalore and of Rehman et al. (2011) for the city of Kanpur. In April 2010 the wind direction was mostly north-westerly, and the temperature was found in the range $35-45^{\circ} \mathrm{C}$. On 15 January 2011 the wind is found to be westerly and temperature to vary in the range $15-20^{\circ} \mathrm{C}$. The time to complete one full circle around the route (Fig. 1) took about 3 to $5 \mathrm{~h}$.

In contrast to MAX-DOAS observations at fixed locations, during car MAX-DOAS observations we have used rather high elevation angles to avoid shades from nearby obstacles (e.g. buildings or trees). From such high elevation angles usually no profile information can be retrieved, but we can obtain the total tropospheric trace gas column density. Measurements at high elevation angles are less affected by aerosols than observations at more low elevation angles.

\subsection{Spectral analysis}

The measured spectra are analysed using the DOAS method (Platt and Stutz, 2008). A wavelength range $435-456 \mathrm{~nm}$ was selected for the analysis. Several trace gas absorption cross sections ( $\mathrm{NO}_{2}$ at $298 \mathrm{~K}$ (Vandaele et al., 1996), $\mathrm{H}_{2} \mathrm{O}$ at $298 \mathrm{~K}$ 


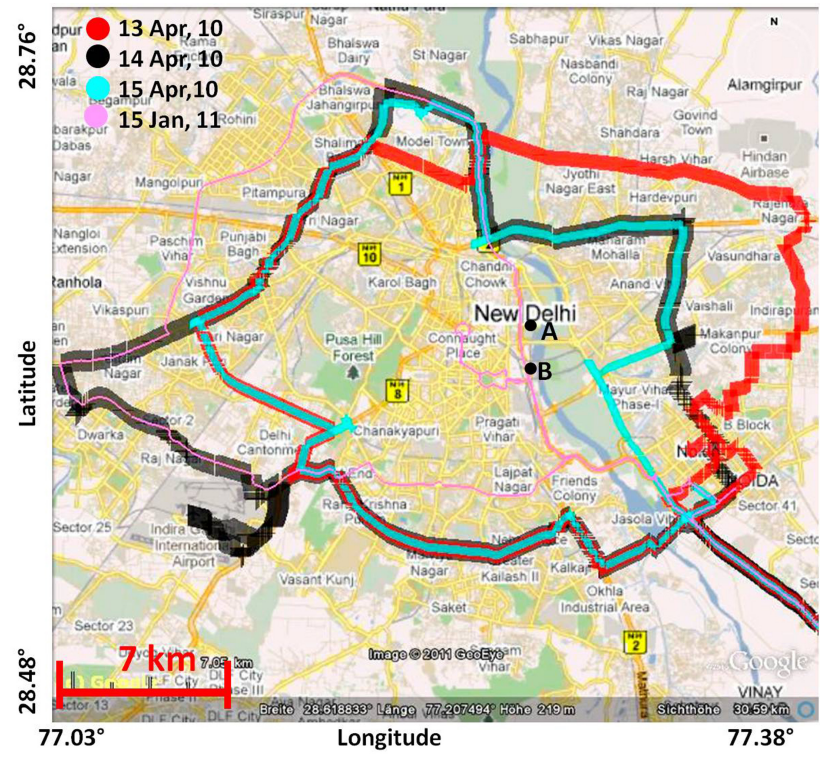

Fig. 1. Different driving routes around Delhi. The points A and B indicate the locations of two power plants Rajghat Power Station and Pragati Gas Power Station, respectively.

(Rothman et al., 2005), Glyoxal at $296 \mathrm{~K}$ (Volkamer et al., 2005), $\mathrm{O}_{3}$ at $243 \mathrm{~K}$ (Bogumil et al., 2003), $\mathrm{O}_{4}$ at $296 \mathrm{~K}$ (Hermans et al., 1999), as well as a Fraunhofer reference spectrum, a Ring spectrum (calculated from the Fraunhofer spectrum) and a polynomial of third order) were included in the spectral fitting process, using the WinDOAS software (Fayt and van Roozendael, 2001). The wavelength calibration was performed based on a high resolution solar spectrum (Kurucz et al., 1984). A typical fit result is shown in Fig. 2. Note that from all fitted trace gases, for the Delhi measurements only the $\mathrm{NO}_{2}$ and $\mathrm{H}_{2} \mathrm{O}$ absorptions were above the detection limit for most measurements.

The output of the spectral analysis is the slant column density (SCD), the integrated trace gas concentration along the light path through the atmosphere. From the spectral analysis, also the uncertainty of the retrieved SCD is determined; for the $\mathrm{NO}_{2}$ analysis it is typically $<15 \%$.

Since a measured spectrum is used as Fraunhofer reference, the retrieval result represents the difference of the SCDs of the measurement at low elevation angle $\alpha$ and the Fraunhofer reference spectrum taken at $90^{\circ}$ elevation, the so called differential SCD or DSCD:

$\operatorname{DSCD}_{\alpha}=\mathrm{SCD}_{\alpha}-\mathrm{SCD}_{\text {Fraunhofer }}$

We have considered elevation angles $(\alpha)$ of $22^{\circ}$ for measurements during April 2010 and of $30^{\circ}$ during January 2011. We considered $\mathrm{DSCD}_{\alpha} \mathrm{s}$ with RMS of residuals smaller than $2.5 \times 10^{-3}$.

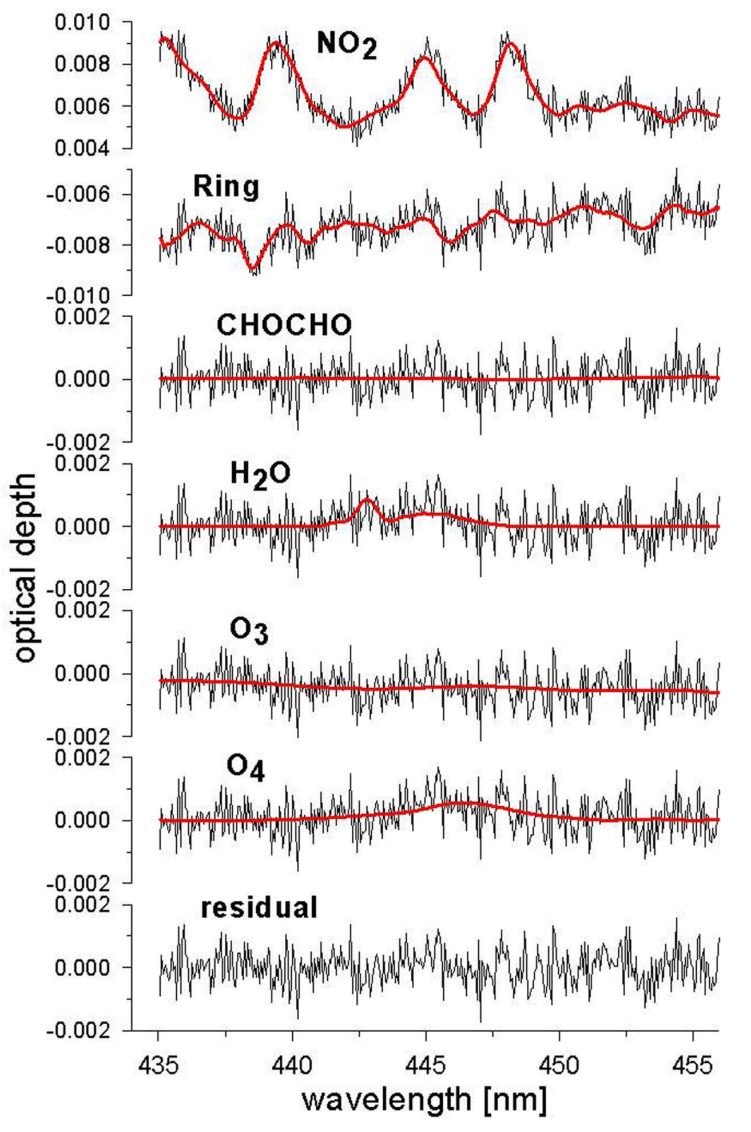

Fig. 2. Typical result of the DOAS fit. Shown are the $\mathrm{NO}_{2}$ crosssection scaled by the respective absorption of the measured spectrum (black). The red curve shows in addition the fit residual.

\subsection{Estimation of the tropospheric VCD}

To determine the $\mathrm{SCD}_{\alpha}$ of a measurement, the $\mathrm{SCD}_{\text {Fraunhofer }}$ (together with the change of the stratospheric SCD) has to be added to the $\operatorname{DSCD}_{\alpha}$ as discussed earlier by Wagner et al. (2010) and Ibrahim et al. (2010). The $\mathrm{VCD}_{\text {trop }}$ is obtained from the $\mathrm{SCD}_{\alpha}$ by dividing by the air mass factor (AMF):

$\mathrm{VCD}_{\text {trop }}=\mathrm{SCD}_{\alpha} / \mathrm{AMF}_{\alpha}$

For many applications, the AMF is retrieved from radiative transfer simulations (Solomon et al., 1987), but here the so called geometric approximation (Brinksma et al., 2008, A. Richter, personal communication, 2006) is used:

$\operatorname{AMF}(\alpha)=1 / \sin (\alpha)$

Using Eq. (3), the tropospheric AMF were found to be 2.67 and 2 for elevation angles of $22^{\circ}$ and $30^{\circ}$, respectively. Depending on the aerosol load, cloud condition and vertical trace gas profile, the true AMF can show substantial deviations from the geometric approximation. However, $\mathrm{NO}_{2}$ is generally located near the surface; therefore the deviations for our measurements are expected to be small (see next section). 


\subsection{Effect of aerosols on the measurements}

The geometric approximation for the tropospheric AMF (Eq. 3) is only valid if the light path through the trace gas layer of interest can be well approximated by a simple geometric path. This assumption is usually fulfilled for shallow trace gas layers and low aerosol loads, since the observed light is typically scattered from above the trace gas layer. But in the presence of high aerosol extinction, a substantial fraction of the observed light might be scattered from inside the trace gas layer and the geometric approximation is not appropriate for the complete trace gas layer.

Depending on the elevation angle and the amount and properties of the aerosols, scattering inside the trace gas layer may either increase (for high elevation angles) or decrease (for lower elevation angles) the true AMF compared to the geometric approximation (Wagner et al., 2004). Thus, the true tropospheric trace gas VCD will be either over- or underestimated.

We have quantified these deviations from the geometric approximation using the Monte Carlo radiative transfer model McARTIM (Deutschmann et al., 2011) for various aerosol scenarios and $\mathrm{NO}_{2}$ layer heights (see Fig. 3). For these sensitivity studies the aerosol optical parameters were chosen as follows: single scattering albedo: 0.95 and asymmetry parameter: 0.68 (see Dubovik et al., 2002). To investigate the effect of different aerosol optical properties we performed similar sensitivity studies as in Fig. 3, but for different values of the single scattering albedo and the asymmetry parameter (see Appendix A). The differences to the results in Fig. 3 are small compared to the effects of the aerosol optical depth and the $\mathrm{NO}_{2}$ and aerosol layer heights. The most important result of these simulation studies is that for $\mathrm{NO}_{2}$ layer heights $\leq 500 \mathrm{~m}$ and for moderate aerosol optical depth (about $<1$ ), the deviations from the geometric approximation are found to be in the order of up to $\pm 20 \%$ (see results for elevation angle of $22^{\circ}$ in Fig. 3). For measurements at an elevation angle of $30^{\circ}$ (15 January 2011) similar results are found (not shown). Here it is important to note that recent MAX-DOAS measurements indicated that the height of the $\mathrm{NO}_{2}$ layer is typically systematically lower than the mixing layer height. For example, MAX-DOAS observations in Milan in September 2003 (Wagner et al., 2011) show rather low $\mathrm{NO}_{2}$ layer heights typically $<500 \mathrm{~m}$. Interestingly, for these measurements the layer heights for $\mathrm{HCHO}$ and aerosols were found to be systematically higher. These findings can be understood by (a) the rather short lifetime of $\mathrm{NO}_{\mathrm{x}}$ compared to aerosols and (b) the fact that $\mathrm{HCHO}$ and aerosols might even be formed when air masses are lifted up, while $\mathrm{NO}_{\mathrm{x}}$ is gradually destroyed. Even for measurements downwind of strong $\mathrm{NO}_{\mathrm{x}}$ emission sources like at Cabauw, The Netherlands, $\mathrm{NO}_{2}$ layer heights of the order of $500 \mathrm{~m}$ or below were often found (Piters et al., 2011). These findings indicate that usually the $\mathrm{NO}_{2}$ profile is systematically lower than the mixing layer height.
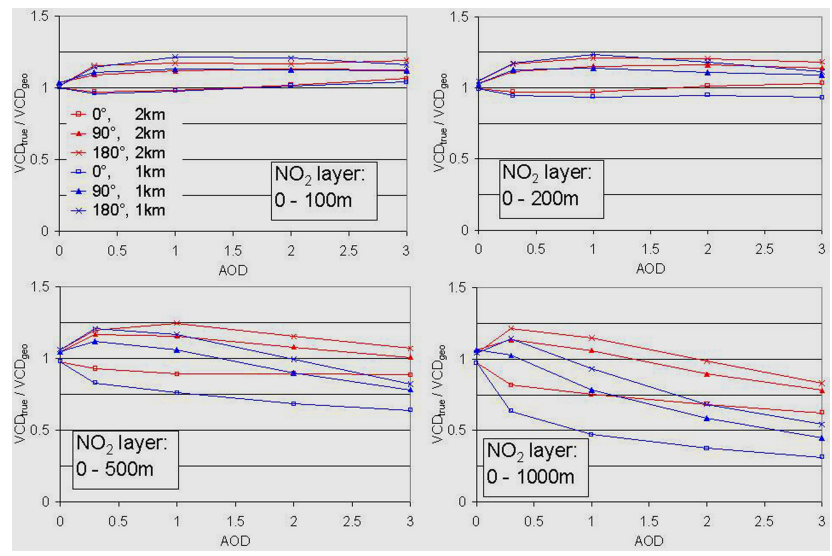

Fig. 3. Relative deviation of the true tropospheric VCDs (derived from radiative transfer simulations) from the geometric VCD for different trace gas layer heights, aerosol optical depth, aerosol layer heights and relative azimuth angles (i.e. the difference of the azimuth angles of the sun and the viewing direction at the telescope). Calculations are performed for an elevation angle of $22^{\circ}$; the results for an elevation angle of $30^{\circ}$ (not shown) are similar.

As shown in Fig. 3 and in the appendix, the relative azimuth angle between the viewing direction and the sun position has a systematic effect on the sensitivity of the MAXDOAS measurements. In general, measurements with relative azimuth angles close to zero tend to underestimate the true $\mathrm{NO}_{2} \mathrm{VCD}$, while measurements at larger relative azimuth angles tend to overestimate the true $\mathrm{NO}_{2}$ VCDs. This systematic dependence on the relative azimuth angle is found for all combinations of $\mathrm{NO}_{2}$ layer heights and aerosol properties (although with different amplitudes). Future studies might explicitly consider this azimuth dependence if tropospheric trace gas VCDs are retrieved from MAX-DOAS observations using high elevation angles. For simplicity, in this study, we only applied an azimuth dependent correction for measurements with strongly enhanced $\mathrm{NO}_{2} \mathrm{VCDs}$ (see Fig. 4), because they have the strongest influence on the derived emission estimate. For this correction we assumed a $\mathrm{NO}_{2}$ layer height of $500 \mathrm{~m}$ and an aerosol layer height of $2000 \mathrm{~m}$. With this simple correction we took already into account part of the variability shown in Fig. 3. Remaining error due to the dependence of the AMF on the $\mathrm{NO}_{2}$ profile, aerosol layer height and aerosol optical properties is estimated to about $20 \%$. Here it is interesting to note that the possible presence of uplifted aerosol layers (e.g. Babu et al., 2011) has only negligible influence on the $\mathrm{NO}_{2}$ AMF (see Appendix A).

The error in the spectral retrieval is of the order of $15 \%$ (see Sect. 2.3). Thus, we estimate the total error in the estimation of retrieved tropospheric $\mathrm{NO}_{2} \mathrm{VCD}$ to be about $25 \%$. 

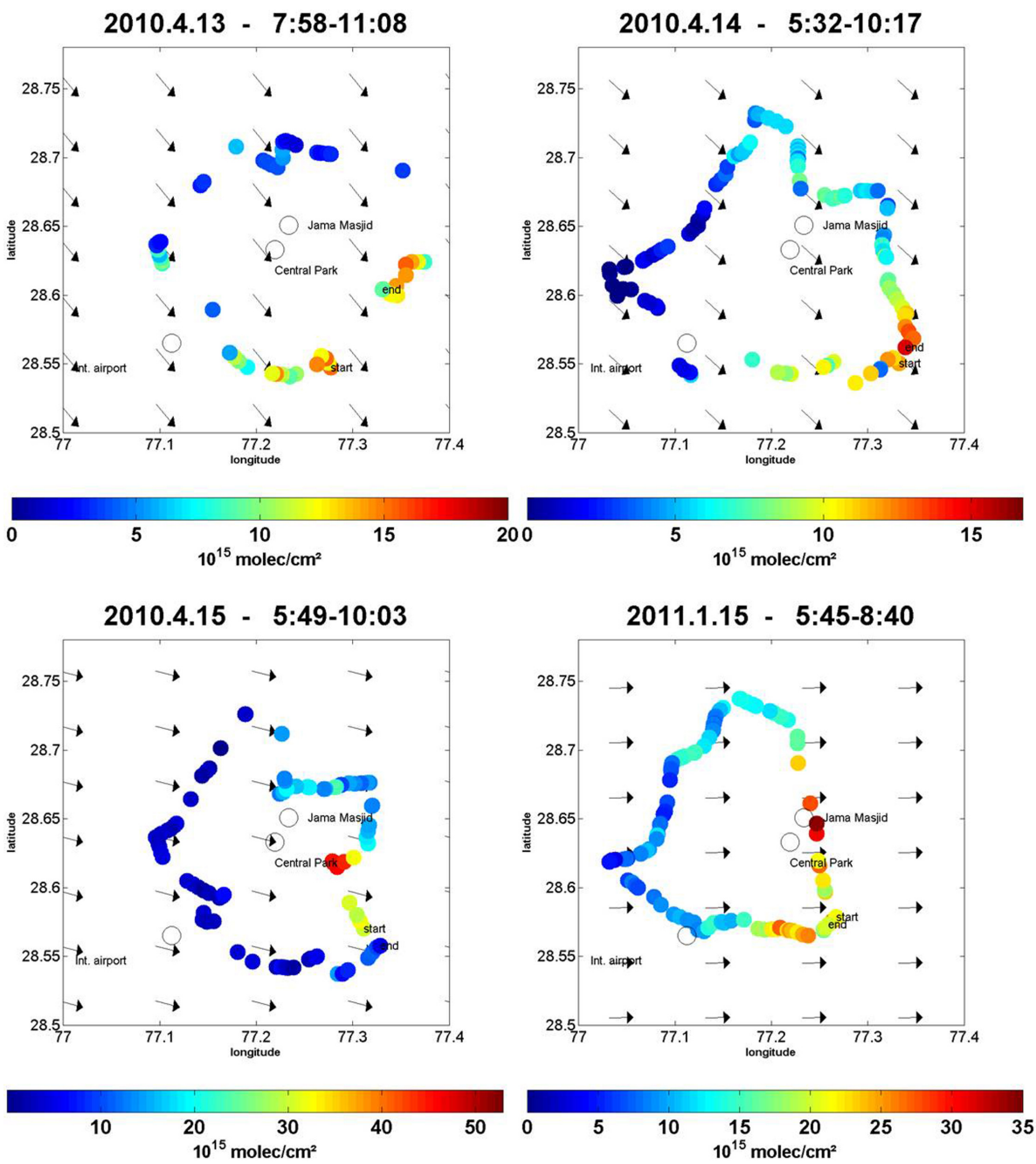

Fig. 4. Tropospheric $\mathrm{NO}_{2}$ VCDs derived from car MAX-DOAS observations around Delhi on different days. The arrows indicate the average wind direction.

\section{Estimation of $\mathrm{NO}_{\mathrm{x}}$ emissions}

\subsection{Emissions from the encircled area}

The total $\mathrm{NO}_{2}$ emissions from the encircled area are determined from the following equation (Ibrahim et al., 2010):

$$
F_{\mathrm{NO}_{2}}=\oint_{S} \operatorname{VCD}_{\mathrm{NO}_{2}}(s) \cdot \bar{w} \cdot \bar{n} \cdot d s
$$

Here $\bar{n}(s)$ indicates the normal vector parallel to the Earth's surface and orthogonal to the driving direction at the position $s$ of the driving route; $\bar{w}$ is the average wind vector within the trace gas layer. The integral of Eq. (4) is evaluated for the MAX-DOAS measurements around Delhi. Because of the finite integration time of individual spectra, the integral is approximated by a sum of the individual polygonal lines.

$$
\begin{aligned}
F_{\mathrm{NO}_{2}} & =\sum_{i} \operatorname{VCD}_{\mathrm{NO}_{2}}\left(s_{i}\right) \cdot \bar{w} \cdot \bar{n} \cdot \Delta s_{i} \\
& =\sum_{i} V C D_{\mathrm{NO}_{2}}\left(s_{i}\right) \cdot w \cdot \sin \left(\beta_{i}\right) \cdot \Delta s_{i}
\end{aligned}
$$

The location, length and direction of each segment is taken from GPS data, which were stored at each second using a GPS-Logger (HOLUX, m.247). The distance between two measurements $\Delta s_{i}$ is taken as the geometric difference between the locations at the beginning of two successive measurements. From the same segment, the angle $\beta_{i}$ between the driving route and the wind direction is calculated.

Wind fields are taken from analyses of the European Centre for Medium-Range Weather Forecasts (ECMWF, full scientific and technical documentations are found from the website http://www.ecmwf.int/research/ifsdocs/CY33r1/ index.html). We considered wind speeds up to $1000 \mathrm{~m}$ and 
weighted them by an assumed exponentially decreasing $\mathrm{NO}_{\mathrm{x}}$ profile with a scale height of $500 \mathrm{~m}$. Since the strongest changes in wind speed and direction occur below about $200 \mathrm{~m}$ altitude, the exact scale height of the assumed $\mathrm{NO}_{\mathrm{x}}$ profile has only little influence on derived effective wind speed and direction. The wind data are linearly interpolated in time for the average MAX-DOAS time.

We estimate the uncertainty of the flux estimation due to the choice of wind fields by (a) varying the scale height of the assumed $\mathrm{NO}_{\mathrm{x}}$ profile by $\pm 200 \mathrm{~m}$ (causing variations within $12 \%$ ), and (b) taking the closest ECMWF output times at 06:00 and 12:00 UTC instead of interpolating (causing variations within $10 \%$ except for January 15 , where the wind fields at 12 UTC have changed significantly, whereas the measurements were taken close to 06:00 UTC). Overall, we estimate the error due to wind fields as $15 \%$.

The measured $\mathrm{NO}_{2}$ VCDs together with the wind fields for the four measurement days are shown in Fig. 4. In general, the highest values of $\mathrm{NO}_{2}$ VCDs are found at the lee side of the city, as expected.

On some days, due to instrument problems, gaps along the driving route occurred; this was mainly due to disturbances caused by uneven road conditions. Due to such problems, $\mathrm{NO}_{2}$ data are missing at some locations, which has contributed to the larger uncertainties in the estimation of the total emissions. We estimate these uncertainties in a simple way: in a first calculation, we determine the total emissions clockwise, in a second calculation counter-clockwise. In both cases, the $\mathrm{NO}_{2} \mathrm{VCD}$ from the last measurements at the beginning of the gap is considered as the true value for the whole gap. From both calculations, we determine the average emissions and the corresponding uncertainties.

In the next step, correction factors accounting for the partitioning between $\mathrm{NO}$ and $\mathrm{NO}_{2}\left(c_{\mathrm{L}}\right)$ and for the finite lifetime of $\mathrm{NO}_{\mathrm{x}}\left(c_{\tau}\right)$ are applied (see Ibrahim et al., 2010) to derive the complete $\mathrm{NO}_{\mathrm{x}}$ emissions from the encircled areas:

$$
F_{\mathrm{NO}_{\mathrm{x}}}=c_{\mathrm{L}} \cdot c_{\tau} \cdot F_{\mathrm{NO}_{2}}
$$

Here $c_{\mathrm{L}}$ is simply the ratio of $\mathrm{NO}_{\mathrm{x}}$ and $\mathrm{NO}_{2}$ in the polluted layer; in urban pollution conditions during daytime we have considered its value to be about 1.32 (Seinfeld and Pandis, $2006)$ with an uncertainty of about $10 \% . c_{\tau}$ describes the ratio of the measured $\mathrm{NO}_{\mathrm{x}}$ and the originally emitted $\mathrm{NO}_{\mathrm{x}}$; it can be estimated from the $\mathrm{NO}_{\mathrm{x}}$ lifetime $\tau$, the wind speed $w$ and the distance of the emission source from the measurements:

$$
c_{\tau}=e^{\frac{t}{\tau}}=e^{\frac{r}{{ }^{\prime} w}}
$$

Here $t$ is the ratio of the radius $(r)$ of the circle and the wind speed $(w)$. Assuming a typical urban plume daytime $\mathrm{NO}_{\mathrm{x}}$ lifetime of $5 \mathrm{~h}$ (Spicer, 1982) and taking into account the wind speed of the individual days, using Eq. (7), we found $c_{\tau}$ in the range of 1.09-1.18 with uncertainties of about \pm 0.1 (assuming uncertainties of the lifetime of $\pm 2 \mathrm{~h}$ ). As mentioned in the previous section corrections for the azimuth dependence of the AMF were applied for the measurements with the highest $\mathrm{NO}_{2} \mathrm{VCDs}$ along the driving routes. These correction factors were calculated for the exact solar zenith angle, solar azimuth angle and viewing direction under the assumption of a $\mathrm{NO}_{2}$ layer height of $500 \mathrm{~m}$ and an aerosol layer height of $2000 \mathrm{~m}$ (see Sect. 2.5). The respective correction factors are: 13 April 2010: 0.84; 14 April 2010: 0.90; 15 April 2010: 0.90; 15 April 2011: 0.84.

The total $\mathrm{NO}_{\mathrm{x}}$ emissions from within the circles on the different days are shown in Fig. 5. Here the error bars show uncertainties due to missing data at some locations (green) or total uncertainties (black). The total $\mathrm{NO}_{\mathrm{x}}$ emissions are found to be similar for the different days within the range of uncertainties between 1.3-1.9 $\times 10^{25}$ molecules per second.

It should be noted that especially close to strong emission sources, part of the emitted NO might not be quickly converted to $\mathrm{NO}_{2}$ if the $\mathrm{NO}$ mixing ratios locally exceed those of $\mathrm{O}_{3}$. In such cases complete establishment of the $\mathrm{NO}_{2} / \mathrm{NO}$ steady state will eventually take place only after ambient air has mixed with the emitted plume (see also Ibrahim et al., 2010). However, for our study such effects can be neglected: First, according to the study of Gurjar et al. (2004) the relative contributions from power plants to the total $\mathrm{NO}_{\mathrm{x}}$ emissions is small (below $10 \%$ ). Thus even if the emissions from power plants were systematically underestimated, the effects on the total emissions would be small.

In addition we estimated the plume extension and the respective $\mathrm{NO}_{\mathrm{x}}$ mixing ratios at the location of the car MAXDOAS measurements according to the atmospheric stability (see Appendix B). We considered the actual wind direction and speed and the distance between the car MAX-DOAS measurements and power plants (see Fig. 1) for the different days. On 13 and 14 April the dilution of the plumes was very effective and $\mathrm{NO}_{\mathrm{x}}$ mixing ratios at the location of the car MAX-DOAS measurements were below the $\mathrm{O}_{3}$ mixing ratios of the ambient air. On 15 April, the $\mathrm{NO}_{\mathrm{x}}$ mixing ratios at the location of the car MAX-DOAS measurements are similar to the $\mathrm{O}_{3}$ mixing ratios of the ambient air and conversion of part of the emitted $\mathrm{NO}_{\mathrm{x}}$ might be hindered. However, on that day the determined emissions are even larger than on the two previous days. On 15 January 2011 the driving route did not surround the power plants. From the overall good consistency of the results for the different days we conclude that the possible limited conversion efficiency of $\mathrm{NO}_{\mathrm{x}}$ to $\mathrm{NO}_{2}$ close to strong emission sources does not play an important role for our study.

\subsection{Up-scaling of emissions for Delhi}

The $\mathrm{NO}_{\mathrm{x}}$ emissions for the different days (Fig. 5) only reflect the emissions from the encircled areas. In order to make these results comparable within each other and to existing emission inventories, the results have to be up-scaled 


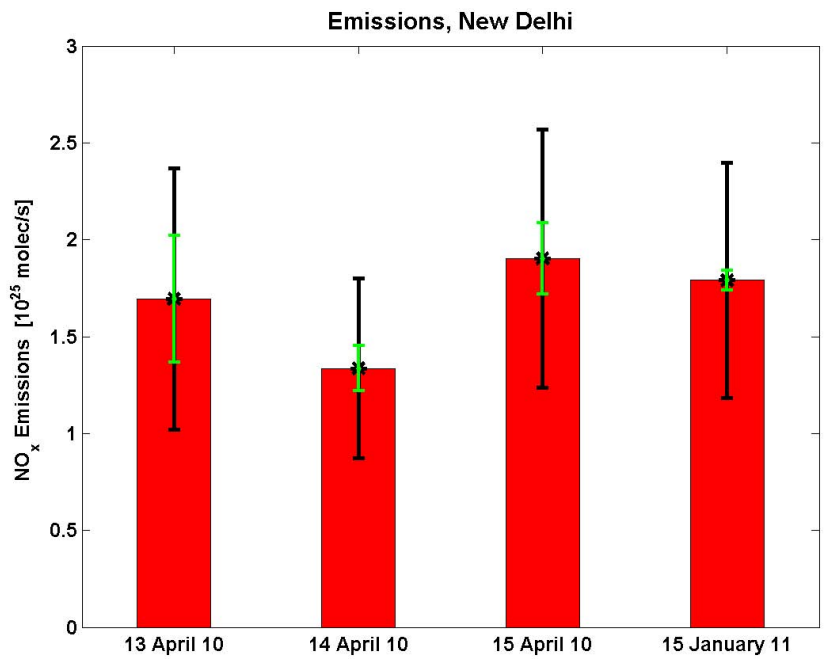

Fig. 5. $\mathrm{NO}_{\mathrm{x}}$ emissions obtained from the car MAX-DOAS measurements for the surrounded areas. The green error bars indicate the uncertainties related to the gaps in the measurements; the black error bars represent the total uncertainty.

to the greater Delhi area (bounded in the region indicated in Fig. 1, latitude $28.5^{\circ} \mathrm{N}$ to $28.77^{\circ} \mathrm{N}$ and longitude $77.0^{\circ} \mathrm{E}$ to $\left.77.4^{\circ} \mathrm{E}\right)$.

For the up-scaling, we used different proxies for the spatial distribution of the $\mathrm{NO}_{\mathrm{x}}$ emissions across the considered area. First, we use the EDGAR emission inventory (version 4.1 for 2005, see Olivier et al., 1998; European commission, 2010), but the spatial resolution of this data set is rather coarse $\left(0.1^{\circ}\right)$. Second, we use data on the population density (obtained from CIESIN, GWPv3, 2010, http://sedac.ciesin.columbia.edu/gpw/global.jsp) with a spatial resolution of $2.5 \mathrm{arc}$ min. Third, we apply the distribution of night-time lights measured from satellite during night (NOAA, National geophysical Data Center, 2006, http: //www.ngdc.noaa.gov/dmsp/download_radcal.html, Ziskin et al., 2010) with a spatial resolution of $0.5 \mathrm{arc}$ min. The respective maps of the different proxies, together with the driving routes of the different days are shown in Fig. 6. For all selected proxies the encircled areas include a substantial fraction of the total Delhi emissions (between 30 and $50 \%$ ), but a slightly larger fraction lies still outside of these circles (see Table 1).

Surprisingly, the calculated fractions using the different proxies are found to be quite similar, that gives us confidence of our up-scaling procedure to determine the total emissions of the selected area. Figure 7 summarises the total $\mathrm{NO}_{\mathrm{x}}$ emissions using the different proxies; it also includes the corresponding $\mathrm{NO}_{\mathrm{x}}$ emissions from the EDGAR data base and a study by Gurjar et al. (2004). Compared to these emission estimates, our results are found to be mostly lower indicating that the existing emission inventories might overestimate the true emissions. However, it should be taken into account
Table 1. Fraction of the EDGAR $\mathrm{NO}_{\mathrm{x}}$ emissions, population, and light within the surrounded areas for the different days.

\begin{tabular}{lccc}
\hline day & $\begin{array}{c}\text { fraction based } \\
\text { on EDGAR emission } \\
\text { density }\end{array}$ & $\begin{array}{c}\text { fraction based } \\
\text { on population } \\
\text { density }\end{array}$ & $\begin{array}{c}\text { fraction based } \\
\text { on night-time } \\
\text { lights }\end{array}$ \\
\hline 13 April 2010 & $43 \%$ & $45 \%$ & $42 \%$ \\
14 April 2010 & $49 \%$ & $42 \%$ & $43 \%$ \\
15 April 2010 & $42 \%$ & $35 \%$ & $35 \%$ \\
15 January 2011 & $36 \%$ & $29 \%$ & $33 \%$ \\
\hline
\end{tabular}

that our results represent only the conditions during a few measurements, while the other inventories are annual averages. Unfortunately, it seems that currently no information on the seasonality (and on the diurnal variation) of the $\mathrm{NO}_{\mathrm{x}}$ emissions is available, which could be used to upscale our emission estimates to the annual average. Unfortunately, existing time series of the $\mathrm{NO}_{\mathrm{x}}$ mixing rations at the surface (e.g. Guttikunda, 2009) can not be directly used for this purpose, because they not only represent the $\mathrm{NO}_{\mathrm{x}}$ emissions but also variations of the mixing layer height and $\mathrm{NO}_{\mathrm{x}}$ lifetime, which also vary with season. In Fig. 7 also the $\mathrm{NO}_{\mathrm{x}}$ emission estimates from OMI satellite observations are included (see Sect. 4.1), which are mostly slightly lower than those from the car MAX-DOAS measurements.

Table 2 lists the different errors of the derived $\mathrm{NO}_{\mathrm{x}}$ emissions. If we assume these errors to be independent, we obtain total uncertainties of about $40 \%$ (see also Ibrahim et al., 2010).

\section{Comparison with OMI satellite data}

In this section we compare the results from the car MAXDOAS measurements to OMI satellite observations in two ways. First, we determine emission estimates for Delhi from the satellite observations and compare them to the respective emissions derived from the car MAX-DOAS observations. Second we compare the $\mathrm{NO}_{2}$ VCDs derived from car MAXDOAS directly to the satellite observations. We use the DOMINO product, v1.02, http://www.temis.nl/airpollution/ no2.html, see Boersma et al. (2007).

\subsection{Estimation of $\mathrm{NO}_{\mathrm{x}}$ emissions from satellite observations}

Satellite observations can be directly used to estimate emission (e.g. Leue et al., 2001; Martin et al., 2003; Beirle et al., 2011). By integration of the tropospheric $\mathrm{NO}_{2}$ VCD from satellite observations across a selected area, the total number of $\mathrm{NO}_{2}$ molecules in the volume above that area can be determined. With the knowledge of the mean $\mathrm{NO}_{\mathrm{x}}$ lifetime the 
Table 2. Uncertainties of the different steps of the emission estimate.

\begin{tabular}{|c|c|c|c|c|c|c|}
\hline Error of & due to & see Sect. & 13 April 2010 & 14 April 2010 & 15 April 2010 & 15 January 2011 \\
\hline SCD & Spectral analysis & 2.3 & & & $15 \%$ & \\
\hline VCD & Geometric Approx. & 2.5 & & & $20 \%$ & \\
\hline \multirow[t]{2}{*}{$\mathrm{NO}_{2}$ flux } & Wind fields & 3.1 & & & $15 \%$ & \\
\hline & Measurement gaps & 3.1 & $21 \%$ & $8 \%$ & $9 \%$ & $1 \%$ \\
\hline \multirow[t]{2}{*}{$\mathrm{NO}_{\mathrm{x}}$ flux } & $c_{\mathrm{L}}$ & 3.1 & & & $10 \%$ & \\
\hline & $c_{\tau}$ & 3.1 & & & $10 \%$ & \\
\hline New Delhi emissions & Upscaling & 3.2 & & & $10 \%$ & \\
\hline Total & Squareroot of quadratic sum & 3.2 & $40 \%$ & $35 \%$ & $35 \%$ & $34 \%$ \\
\hline
\end{tabular}
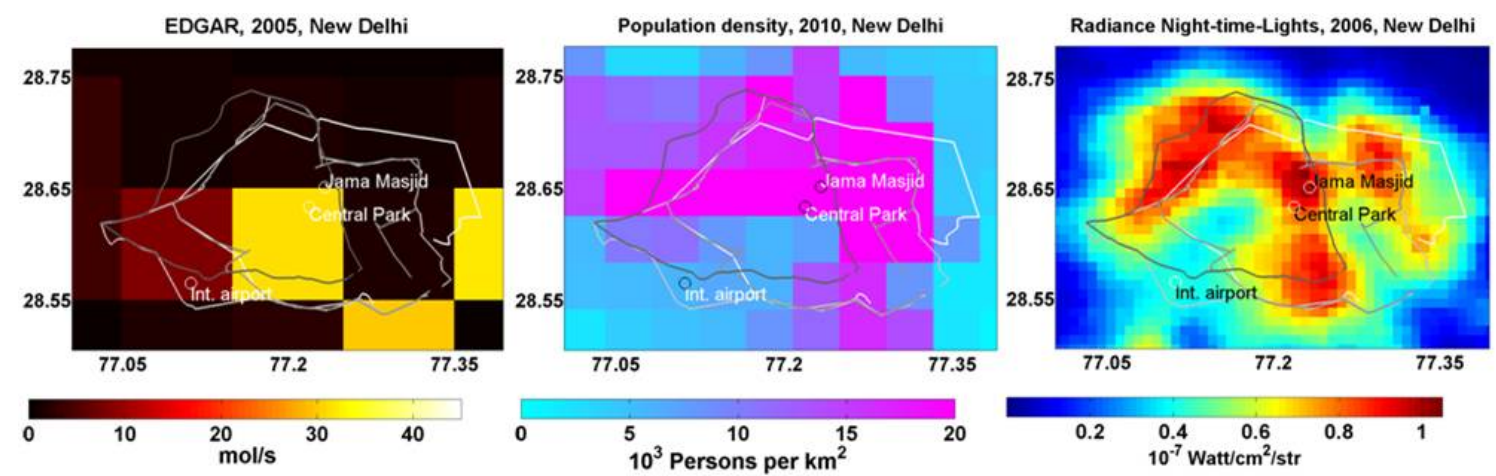

Fig. 6. Spatial distribution of the $\mathrm{NO}_{\mathrm{x}}$ emissions from the EDGAR data base (left), of the population density (center), and the night-time lights (right) for the selected Delhi area (see Fig. 1). Also shown are the driving routes for the different days.

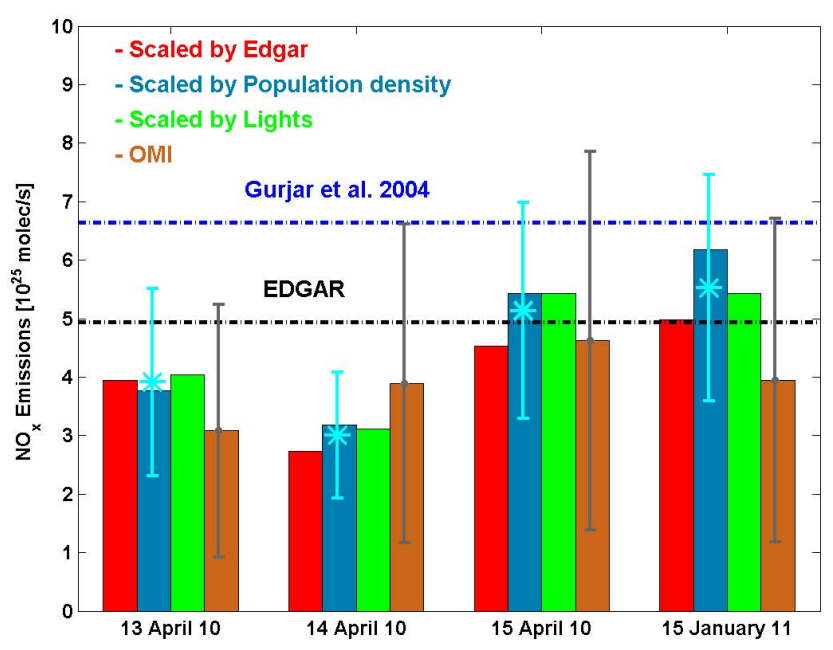

Fig. 7. Comparison of the up-scaled $\mathrm{NO}_{\mathrm{x}}$ emissions from the car MAX-DOAS measurements (using different proxies) and existing emission estimates. The cyan points show the mean emission estimate for each day with the respective total error, as explained in Table 2. The brown columns show emission estimates derived from OMI observations (Sect. 4.1). corresponding emissions can then be simply derived by the following formula:

$F_{\mathrm{NO}_{\mathrm{x}}}=c_{\mathrm{L}} \cdot \frac{\int \mathrm{VCD}_{\mathrm{NO}_{2}} \cdot d A}{\tau}$

The area over which the satellite measurements are integrated have to be chosen carefully. First, it should include the emission source of interest. Second, it should not be significantly influenced by other strong sources from outside or inside the selected area. Third, it should be large enough to contain most of the emitted $\mathrm{NO}_{\mathrm{x}}$, which is advected from the source. In practice this means that the distance between the emission source and the borders of the selected area should be larger than the product of the wind speed and the $\mathrm{NO}_{\mathrm{x}}$ lifetime. Like for the determination of the $\mathrm{NO}_{\mathrm{x}}$ emissions from the car MAX-DOAS observations (Sect. 3.1) we assume the $\mathrm{NO}_{\mathrm{x}}$ lifetime to about $5 \mathrm{~h}$. According to wind speeds on the selected days between 3 and $9 \mathrm{~ms} \mathrm{~s}^{-1}$ this results in a minimum distance between $50 \mathrm{~km}$ and $160 \mathrm{~km}$.

It is interesting to note that in contrast to the car MAXDOAS measurements the uncertainty of the derived $\mathrm{NO}_{\mathrm{x}}$ emissions using equation 8 is directly proportional to the uncertainty of the assumed $\mathrm{NO}_{\mathrm{x}}$ lifetime. While an uncertainty of $\pm 2 \mathrm{~h}$ leads to an uncertainty of about $\pm 10 \%$ for the $\mathrm{NO}_{\mathrm{x}}$ emission estimate from car MAX-DOAS measurements, it 

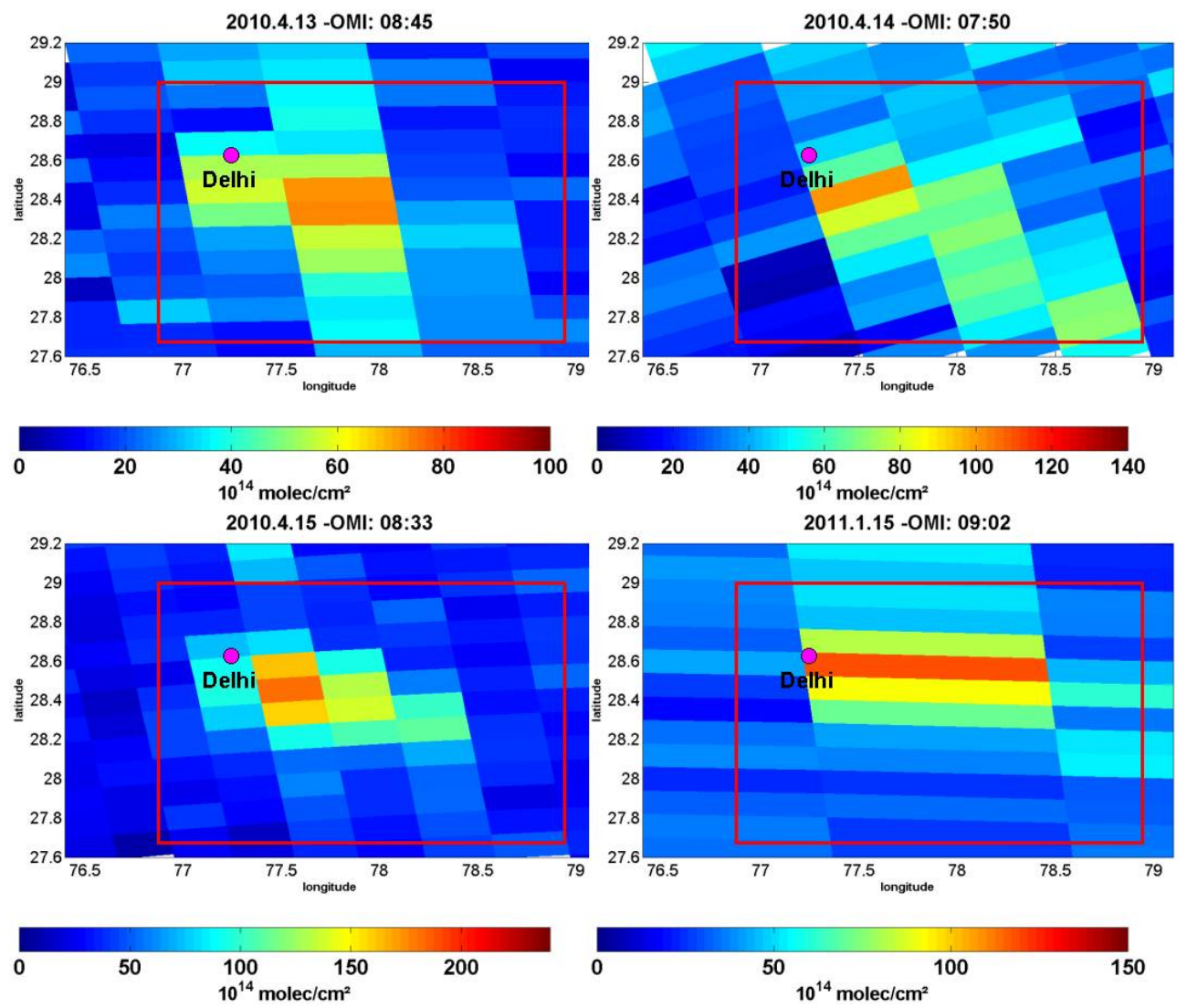

Fig. 8. Tropospheric $\mathrm{NO}_{2}$ VCD measured by OMI around Delhi for the four days, for which the $\mathrm{NO}_{\mathrm{x}}$ emissions were obtained from the car MAX-DOAS measurements. The outflow from the city is clearly visible and follows the wind patterns (see Fig. 4). For the determination of the $\mathrm{NO}_{\mathrm{x}}$ emissions the satellite observations inside the red rectangle were considered. Note the different colour scales.

leads to $\pm 40 \%$ for the $\mathrm{NO}_{\mathrm{x}}$ emission estimate from satellite observations.

In Fig. 8 the spatial distributions of the tropospheric $\mathrm{NO}_{2}$ VCDs observed by OMI around Delhi are shown for the four days on which the $\mathrm{NO}_{\mathrm{x}}$ emissions were determined from car MAX-DOAS measurements. Also shown is the area (red rectangle) over which the satellite $\mathrm{NO}_{2} \mathrm{VCDs}$ are integrated. Since the wind was blowing from mainly westerly directions (see Fig. 4), we chose the area to include large parts of the downwind plume in easterly and southerly directions. On all days the pollution outflow from Delhi is clearly visible in the satellite images.

The next step is to estimate the "background" $\mathrm{NO}_{2} \mathrm{VCDs}$ at the side of the inflow into the city. This "background" $\mathrm{NO}_{2}$ $\mathrm{VCD}$ is then subtracted from the tropospheric $\mathrm{NO}_{2} \mathrm{VCDs}$ before Eq. (8) is applied. We determined the "background" $\mathrm{NO}_{2} \mathrm{VCD}$ from the closest OMI measurements at the inflow side, which were not yet affected by the emissions from the city.

The $\mathrm{NO}_{\mathrm{x}}$ emissions from Delhi derived with this method are also shown in Fig. 7. They are typically slightly lower than those derived from the car MAX-DOAS measurements for the same days. However, the uncertainties of this method are rather large (about $70 \%$ ). Several sources contribute to the total uncertainty: the exact choice of the area over which the satellite measurements are integrated leads to uncertainties of about $40 \%$. We determined this uncertainty by sensitivity studies varying the selected area. In a similar way we determined the uncertainties related to the determination of the "background" $\mathrm{NO}_{2} \mathrm{VCD}$ to about $15 \%$. The uncertainties of the satellite VCDs are about $35 \%$. Finally, the errors caused by the uncertainties of the assumed $\mathrm{NO}_{\mathrm{x}}$ lifetime are about $40 \%$.

\subsection{Validation of OMI measurements using car MAX-DOAS measurements}

Validation of tropospheric trace gas products from satellite observations is a challenging task for several reasons. First, since satellites measure the vertically integrated tropospheric column density, observations of in-situ surface concentrations can not be directly used for validation purposes. Even if vertical profiles are available from aircraft measurements (e.g. Heland et al., 2002) or balloon soundings (e.g. Sluis et al., 2010), they are often not representative for the whole 


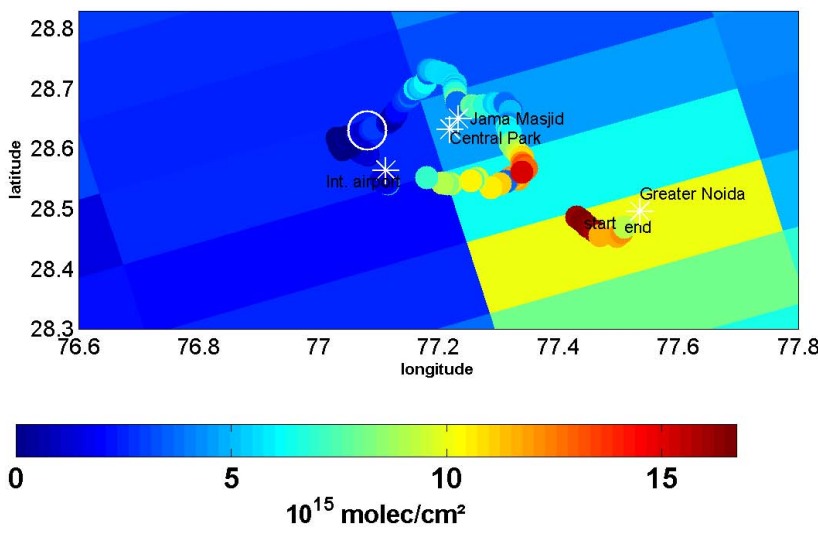

Fig. 9. Comparison of the tropospheric $\mathrm{NO}_{2}$ VCDs on 14 April 2010 measured from OMI and car MAX-DOAS. MAX-DOAS observations were carried out between 05:20 and 10:57 UT; OMI overpass was at 07:50 UT. The large circle indicates MAX-DOAS observations during the OMI overpass.

spatial extent of the satellite ground pixel, which is typically of the order of several hundreds of $\mathrm{km}^{2}$ or more. Similar arguments hold for observations of the integrated tropospheric column measurements e.g. from MAX-DOAS observations at fixed locations (e.g. Brinksma et al., 2008). Here it is important to note that close to strong emission sources like megacities, where the validation of tropospheric satellite products is of highest importance, the largest variability and strongest gradients are typically found (Chen et al., 2009).

Information about the spatial variability across a satellite ground pixel can be obtained from mobile measurements like car MAX-DOAS observations (e.g. Volkamer et al., 2006; Wagner et al., 2010), thus we also use the tropospheric $\mathrm{NO}_{2}$ VCDs obtained during our measurement campaigns in Delhi for the validation of the simultaneous observations of the tropospheric $\mathrm{NO}_{2}$ VCDs from the OMI instrument. We selected OMI satellite observations (Levelt et al., 2002), because the ground pixel sizes are much smaller $\left(\sim 13 \times 26 \mathrm{~km}^{2}\right.$ in nadir geometry) compared to observations from SCIAMACHY and GOME-2. One important aspect of tropospheric satellite observations is the use of a-priori information on the (relative) trace gas profile. For the DOMINO tropospheric $\mathrm{NO}_{2}$ product from OMI observations profile data from from model simulations (TM4) are sued for that purpose. The specific choice of the $\mathrm{NO}_{2}$ profile has a strong effect on the retrieved $\mathrm{NO}_{2} \mathrm{VCD}$, since the sensitivity of the satellite observations strongly depend on altitude (Boersma et al., 2011). One particular critical aspect of the use of model data is that the spatial resolution of the model $\left(2^{\circ}\right.$ latitude and $3^{\circ}$ longitude) is much coarser than the spatial scales of tropospheric $\mathrm{NO}_{2}$ field close to strong emission sources (see Heckel et al., 2011). Thus for model grid cells including strong emission sources the average $\mathrm{NO}_{2}$ profile must necessarily be a compromise between those over the source regions and those of the outflow regions.

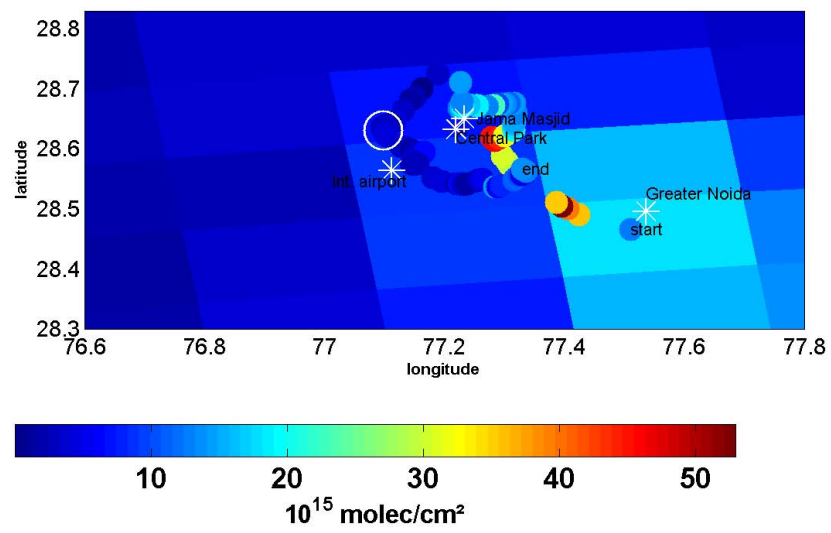

Fig. 10. Comparison of the tropospheric $\mathrm{NO}_{2}$ VCDs on 15 April 2010 measured from OMI and car MAX-DOAS. MAX-DOAS observations were carried out between 05:05 and 10:06 UT; OMI overpass was at 08:33 UT. The large circle indicates MAX-DOAS observations during the OMI overpass.

Figure 9 shows the comparison of the tropospheric $\mathrm{NO}_{2}$ VCDs on 14 April 2010 from mobile MAX-DOAS and OMI observations. On that day, OMI observes Delhi at relatively slant viewing angles, and the ground pixel sizes are rather large. Thus, the car MAX-DOAS observations cover only relatively small fractions of the individual ground pixels. Nevertheless, in both data sets the same general distribution of $\mathrm{NO}_{2}$ is observed: highest values of $\mathrm{NO}_{2}$ are found in the south east, which is consistent with the wind direction on that day (north-westerly wind, see Fig. 4). The car MAX-DOAS observations reveal much finer spatial patterns with stronger spatial gradients, which are not resolved from the OMI data.

The comparison of the tropospheric $\mathrm{NO}_{2} \mathrm{VCDs}$ for 15 April 2010 is shown in Fig. 10. On that day the OMI observations were made almost vertically (nadir geometry), and the satellite pixels are much smaller compared to the observations made on 14 April 2010. Both satellite ground pixels over Delhi are well covered by the car MAX-DOAS observations and similar spatial patterns were observed in both data sets. Again, the car MAX-DOAS observations resolve details on a much finer scale.

Figure 11 shows another validation example from 16 January 2011, when MAX-DOAS observations were carried out along a route from Delhi to Agra (about $225 \mathrm{~km}$ ). Like in the previous examples the general distribution of the tropospheric $\mathrm{NO}_{2} \mathrm{VCD}$ is found to be similar in both data sets with the highest values at or close to Delhi. An interesting finding is that OMI underestimates the high values over Delhi, but overestimates the low values over rural regions along the route Delhi to Agra.

Figure 12 shows a correlation analysis of all car MAXDOAS observations (during April 2010 and January 2011) and the coincident OMI satellite data (blue points). Here, all MAX-DOAS observations within an OMI ground pixels were averaged. The error bars indicate the OMI error 


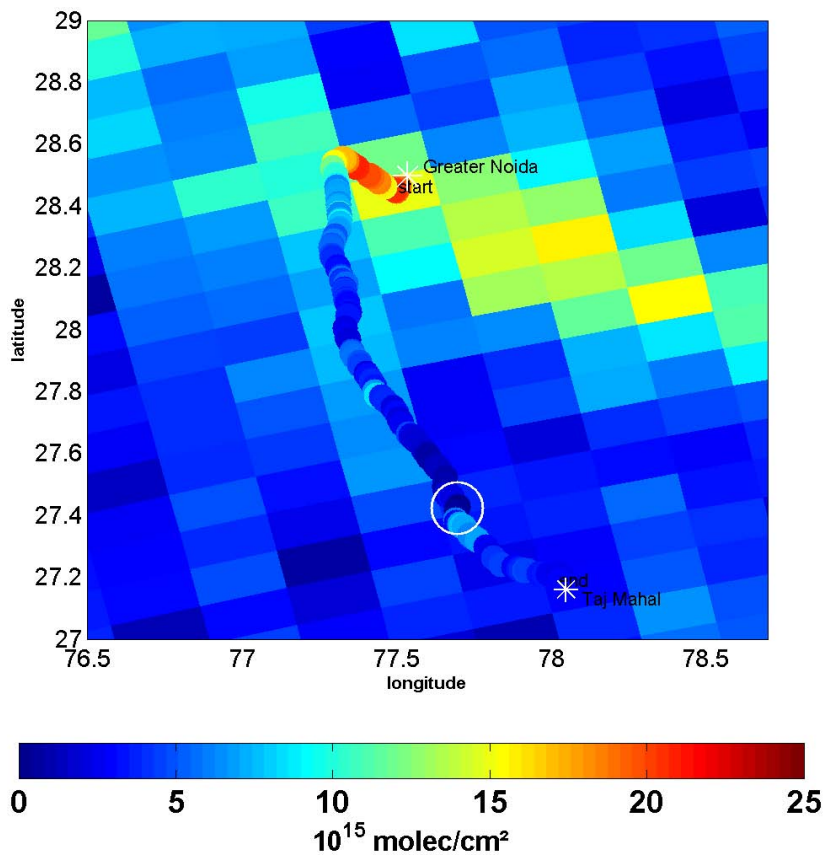

Fig. 11. Comparison of the tropospheric $\mathrm{NO}_{2}$ VCDs on 16 January 2011 measured from OMI and car MAX-DOAS from New Delhi to Agra (Taj Mahal). MAX-DOAS observations were carried out between 04:33 and 09:05 UT; OMI overpass was at 08:06 UT. The large circle indicates MAX-DOAS observations during the OMI overpass.

and the standard deviation of the MAX-DOAS observations, respectively. Using these errors, we performed an orthogonal regression (Cantrell, 2008). A reasonable correlation (coefficient of determination $r^{2}=0.48$ ) is found, but the slope $(0.38)$ deviates strongly from unity. In contrast, the ratio of the average of all OMI VCDs $\left(5.7 \pm 2.7 \times 10^{15} \mathrm{molec} \mathrm{cm}^{-2}\right)$ to the average of the MAXDOAS observations $\left(8.5 \pm 4.4 \times 10^{15} \mathrm{molec} \mathrm{cm}^{-2}\right)$ is 0.77 , and the average of the individual ratios is even 1.07.

In order to investigate the effect of limited spatial sampling in the presence of strong gradients in more detail, a second comparison was made including only observations, for which the car MAX-DOAS observations cover large fractions of the OMI pixels (at least $50 \%$ in east-west direction (defined by the most eastern and most western MAX-DOAS observation within the OMI pixel) like e.g. shown in Fig. 10). Only five measurements fulfilled this criterion. If only these observations are considered, a better correlation (coefficient of determination $r^{2}=0.79$ ) is obtained, but the results of the orthogonal regression are almost unchanged.

A general finding of this comparison is that over polluted sites the OMI tropospheric $\mathrm{NO}_{2}$ VCDs are systematically smaller than those from the car MAX-DOAS measurements, while for areas with low pollution levels the opposite behaviour is found.

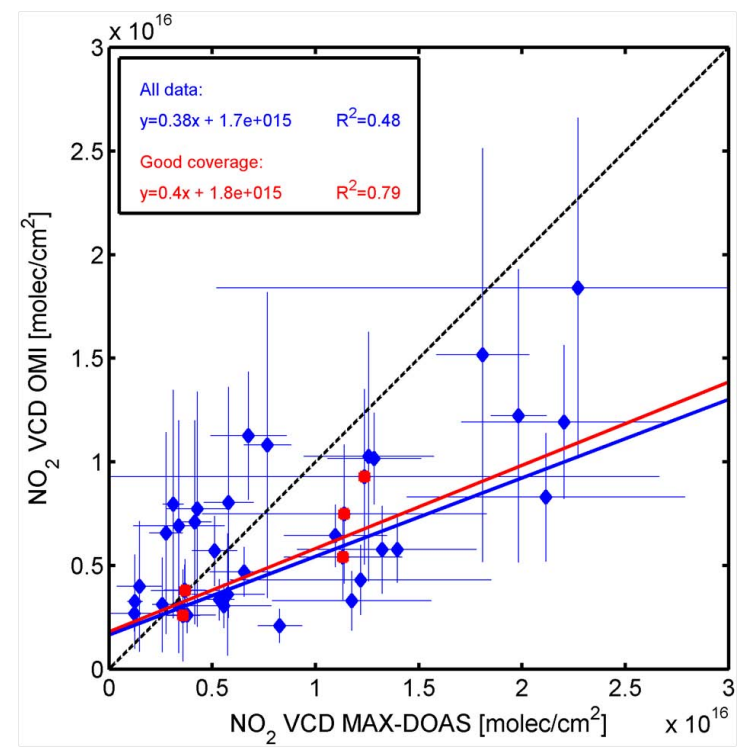

Fig. 12. Correlation analysis of OMI and car MAX-DOAS observations of the tropospheric $\mathrm{NO}_{2}$ VCD during April 2010 and January 2011. Blue dots represent all coincident measurements; red dots represent measurements where the OMI ground pixels were mostly covered (at least $50 \%$ in east-west dimension) by the car MAXDOAS measurements (like in Fig. 9).

The underestimation of high tropospheric $\mathrm{NO}_{2} \mathrm{VCDs}$ by OMI might be partly caused by the shielding of the surfacenear $\mathrm{NO}_{2}$ by aerosols. Here it should, however, be noted that the (effective) cloud fractions for the OMI observations used in our study are found to be very low: $2.3 \%$ on average for all observations; $<1.2 \%$ for the sub-set of OMI pixels, which are well covered by the car MAX-DOAS observations. Thus, effects of cloud shielding is considered to be negligible here. Part of the underestimation might also be related to differences between the true (relative) $\mathrm{NO}_{2}$ height profiles and those assumed in the satellite retrieval. If e.g. the assumed profiles contain a smaller fraction close to the surface compared to the true profiles, the respective tropospheric AMFs overestimate the true tropospheric AMFs, and consequently, the retrieved tropospheric $\mathrm{NO}_{2} \mathrm{VCDs}$ underestimate the true tropospheric $\mathrm{NO}_{2}$ VCDs (Boersma et al., 2009). Of course also the uncertainties of the car MAX-DOAS measurements might contribute to the deviations, but especially for $\mathrm{NO}_{2}$ profiles with low layer heights, the uncertainties of the car MAX-DOAS measurements are smaller than for the satellite observations.

Different conclusions can be drawn for the less polluted areas. Here the OMI tropospheric $\mathrm{NO}_{2}$ VCDs probably overestimate the true $\mathrm{NO}_{2}$ VCDs, because the $\mathrm{NO}_{2}$ profile assumed for the retrieval probably overestimates the $\mathrm{NO}_{2}$ concentrations close to the surface. But for less polluted regions, also the uncertainties of the car MAX-DOAS observations probably substantially contribute to the discrepancies between 
both data sets. Because of the larger fraction of the $\mathrm{NO}_{2}$ at higher altitudes the uncertainties of the car MAX-DOAS observations become larger than for measurements close to strong emission sources (see Fig. 3). Moreover, for the measurements between Delhi and Agra on 15 January 2011 the car MAX-DOAS observations might systematically underestimate the true tropospheric $\mathrm{NO}_{2} \mathrm{VCD}$, because the relative azimuth angle is close to zero for large parts of the driving route (Fig. 3 and Appendix A).

It should be noted that existing validation studies show quite controversial results: studies based on in-situ observations (at the surface or from aircraft) and LIDAR observations indicate that the troposheric $\mathrm{NO}_{2} \mathrm{VCD}$ (DOMINO, v1.02) derived from OMI observations is biased high (Boersma et al., 2011; Hains et al., 2010 and reference therein). In contrast, studies based on MAX-DOAS observations (Brinksma et al., 2008; Celarier et al., 2008) indicate that the troposheric $\mathrm{NO}_{2} \mathrm{VCD}$ derived from $\mathrm{OMI}$ is biased low. The latter results are in agreement with the findings of our validation study.

\section{Conclusions}

Car MAX-DOAS observations were performed in the greater Delhi area during April 2010 and January 2011. The aims of the measurements were first the determination of the total $\mathrm{NO}_{\mathrm{x}}$ emissions of the greater Delhi area and second the validation of satellite observations.

The total $\mathrm{NO}_{\mathrm{x}}$ emissions were derived from observations along closed circles around the city. Since the MAX-DOAS observations encircled only part of the entire Delhi area, we had to up-scale our results. For that purpose we used three different proxies: the spatial distribution of (a) the $\mathrm{NO}_{\mathrm{x}}$ emissions from the EDGAR emission inventory, (b) the population density, and (c) the light intensity observed from satellite during night. Although the first two proxies have rather coarse spatial resolution, the up-scaled results using the three proxies agree well (within $20 \%$ ). Two additional corrections were applied to account for the partitioning of $\mathrm{NO}$ and $\mathrm{NO}_{2}$ and for the limited lifetime of $\mathrm{NO}_{\mathrm{x}}$ (leading to destruction of part of the emitted $\mathrm{NO}_{\mathrm{x}}$ between the locations of the emission source and the observation). The overall uncertainty of our emission estimate is about $40 \%$, taking into account measurement uncertainties and uncertainties of the various assumptions. From four measured circles around Delhi (three during April 2010 and one in January 2011) an average $\mathrm{NO}_{\mathrm{x}}$ emission of $4.4 \times 10^{25}$ molecules s ${ }^{-1}$ was derived. The results from the four days were found to agree within $\pm 40 \%$.

Our $\mathrm{NO}_{\mathrm{x}}$ emission estimate is slightly lower than $\mathrm{NO}_{\mathrm{x}}$ emissions from the EDGAR data base (v4.1) $\left(4.94 \times 10^{25}\right.$ molec s $\left.^{-1}\right)$ and substantially lower than from a recent study by Gurjar et al. (2004) $\left(6.42 \times 10^{25}\right.$ molec s $\left.^{-1}\right)$. However, no exact agreement should be expected, because our measurements represent short periods during two months of two contrast seasons (winter and summer), whereas the values from emission inventories are annual averages.

We also $\mathrm{NO}_{\mathrm{x}}$ emissions from Delhi using OMI satellite observations on the same days as for the car MAX-DOAS measurements. These emissions are slightly smaller than those from the car MAX-DOAS measurements.

The MAX-DOAS observations were also used for the validation of tropospheric OMI NO2 VCDs. We chose OMI observations because of its relatively small pixel sizes. In general, similar spatial patterns are found in both data sets, but with a much finer spatial resolution in the car MAXDOAS data. The comparison of absolute values show overall a fair agreement. However, over highly polluted regions the OMI observations are systematically smaller than the car MAX-DOAS measurements. Most probably, this difference is caused by the a-priori vertical $\mathrm{NO}_{2}$ profile assumed in the OMI retrieval. In less polluted regions, OMI tropospheric $\mathrm{NO}_{2}$ VCDs are larger than those from car MAX-DOAS observations, but under such conditions large part of the differences might be also caused by the errors of the car MAXDOAS observations.

\section{Appendix A}

\section{Investigating the effects of aerosols on the car MAXDOAS measurements}

As shown in the main text of the paper (Sects. 2.5 and Fig. 3), aerosols cause modifications of the atmospheric radiation field compared to clear sky. These modifications lead to deviations from the assumptions of geometric light paths through the trace gas layers of interest. In Fig. 3 of the main text the relative differences to the so called geometric approximation (Eq. 3) are shown for various $\mathrm{NO}_{2}$ and aerosol profiles and aerosol optical properties. The differences become particularly large for cases of strong aerosol optical depth and high trace gas layer height. The results shown in Fig. 3 represent aerosols with asymmetry parameter of 0.68 and single scattering albedo of 0.95 which are typical for polluted urban regions (see Dubovik et al., 2002). In this appendix we explore the effects of variations of aerosol optical properties. In addition, we also investigate the effects of elevated aerosol layers.

In Fig. A1 the optical properties of the aerosol are changed. The single scattering albedo is varied from 0.9 to 1.0 , and the asymmetry parameter is varied from 0.6 to 0.75 . Both variations have additional systematic effects on the sensitivity of the measurements but compared to the main effects (aerosol optical depth and trace gas layer height) these changes are small.

In Fig. A2 we investigate the effect of elevated aerosol layers (between 2 and $3 \mathrm{~km}$ and between 8 and $9 \mathrm{~km}$ ), which were e.g. observed by Babu et al. (2011). We used the same $\mathrm{NO}_{2}$ profiles as in Fig. 3 and Fig. A1. Compared to aerosol 
a) Asymmetry parameter: 0.6, Single scattering albdo: 0.95
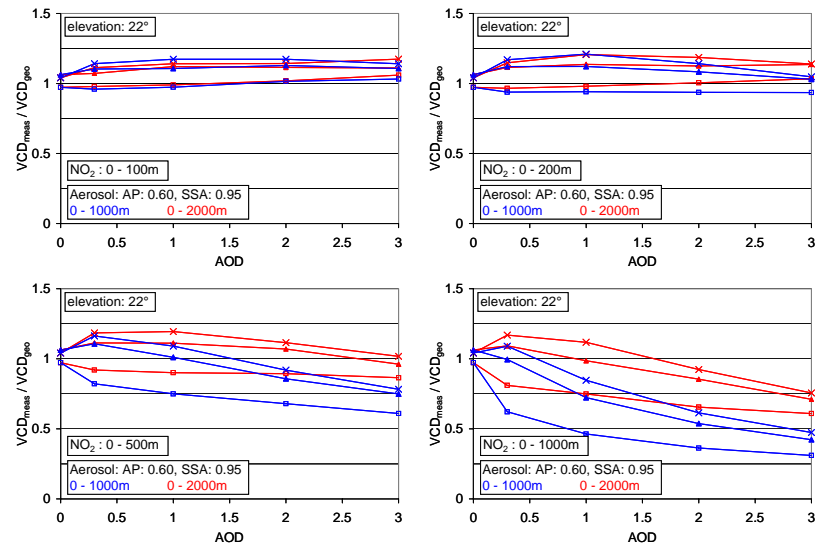

c) Asymmetry parameter: 0.68 , Single scattering albdo: 0.9
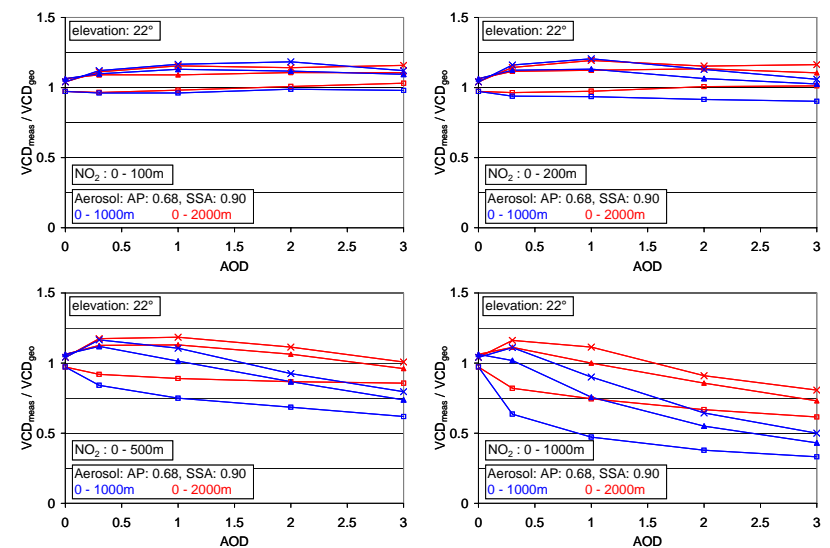

b) Asymmetry parameter: 0.75 , Single scattering albdo: 0.95
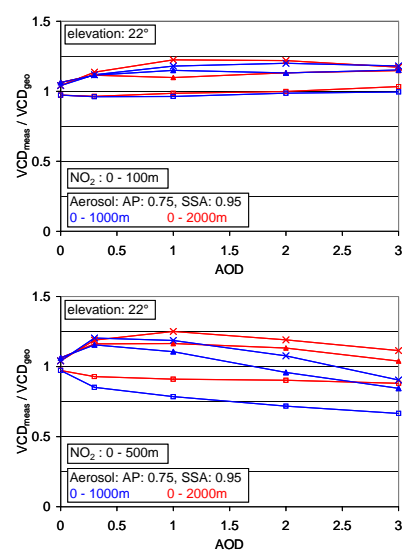
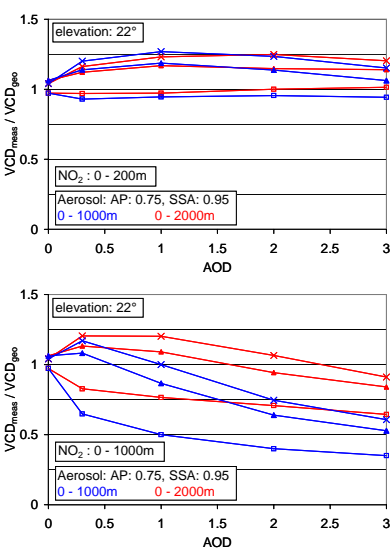

d) Asymmetry parameter: 0.68 , Single scattering albdo: 1
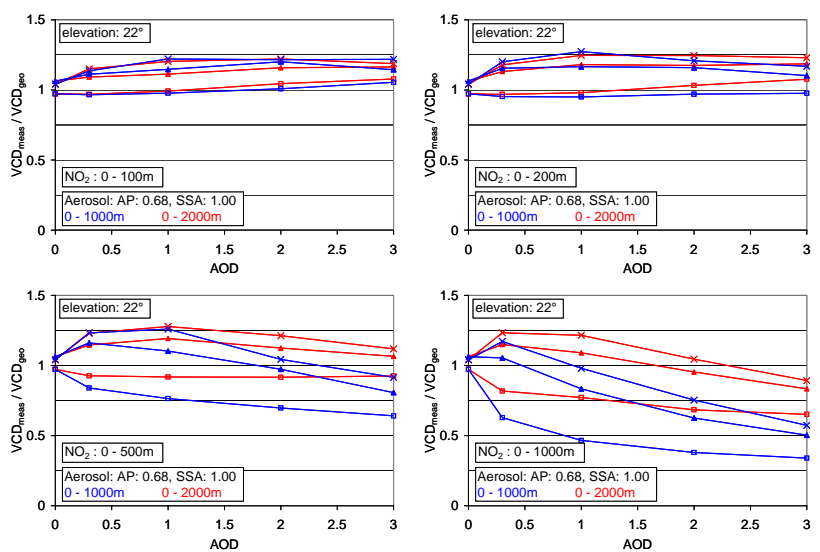

Fig. A1. Relative deviation of the true tropospheric VCDs (derived from radiative transfer simulations) from the geometric VCD for different trace gas layer heights, aerosol optical depth, aerosol layer heights and relative azimuth angles. Panels (a) to (d) show the results for different aerosol optical properties.

layers close to the surface, elevated aerosol layers lead only to rather small deviations from the geometric approximation. This finding indicates that elevated aerosols have only small influence on the light paths in the line of sight of the instrument close to the surface. We conclude that the possible presence of elevated aerosol layers can be neglected for the interpretation of our measurements.

In Fig. A3 we present similar data as shown in Fig. 3, but they are displayed now as function of the relative azimuth angle or SZA. For small SZA, the geometric approximation generally leads to an overestimation of the trace gas VCD, while for large SZA also an underestimation is found. This underestimation is especially strong for high trace gas layers, relative azimuth angles and SZA around $50-60^{\circ}$.

The azimuth dependence is shown in more detail in Fig. A4. While for an aerosol-free atmosphere the azimuth dependence is weak, it increases with aerosol optical depth and aerosol layer height.
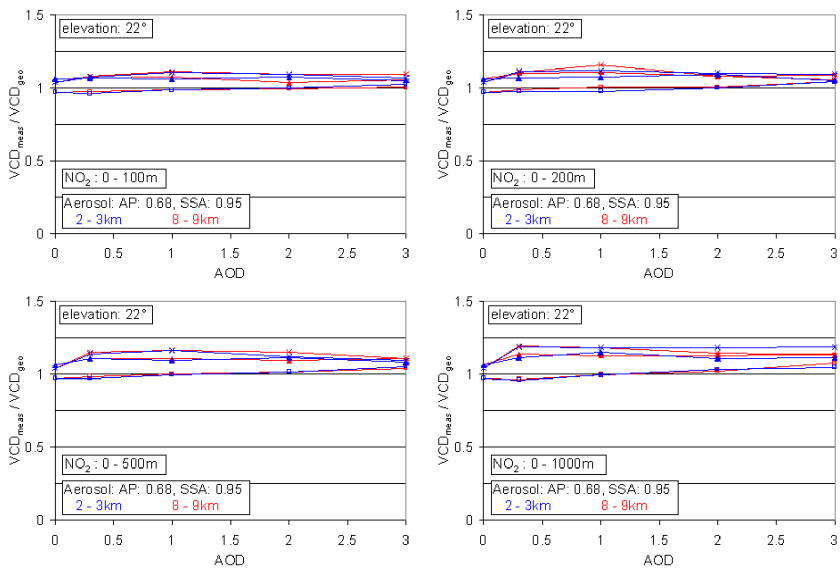

Fig. A2. Like Fig. A1a, but for elevated aerosol layers $(2-3 \mathrm{~km}$, blue; $8-9 \mathrm{~km}$, red). 

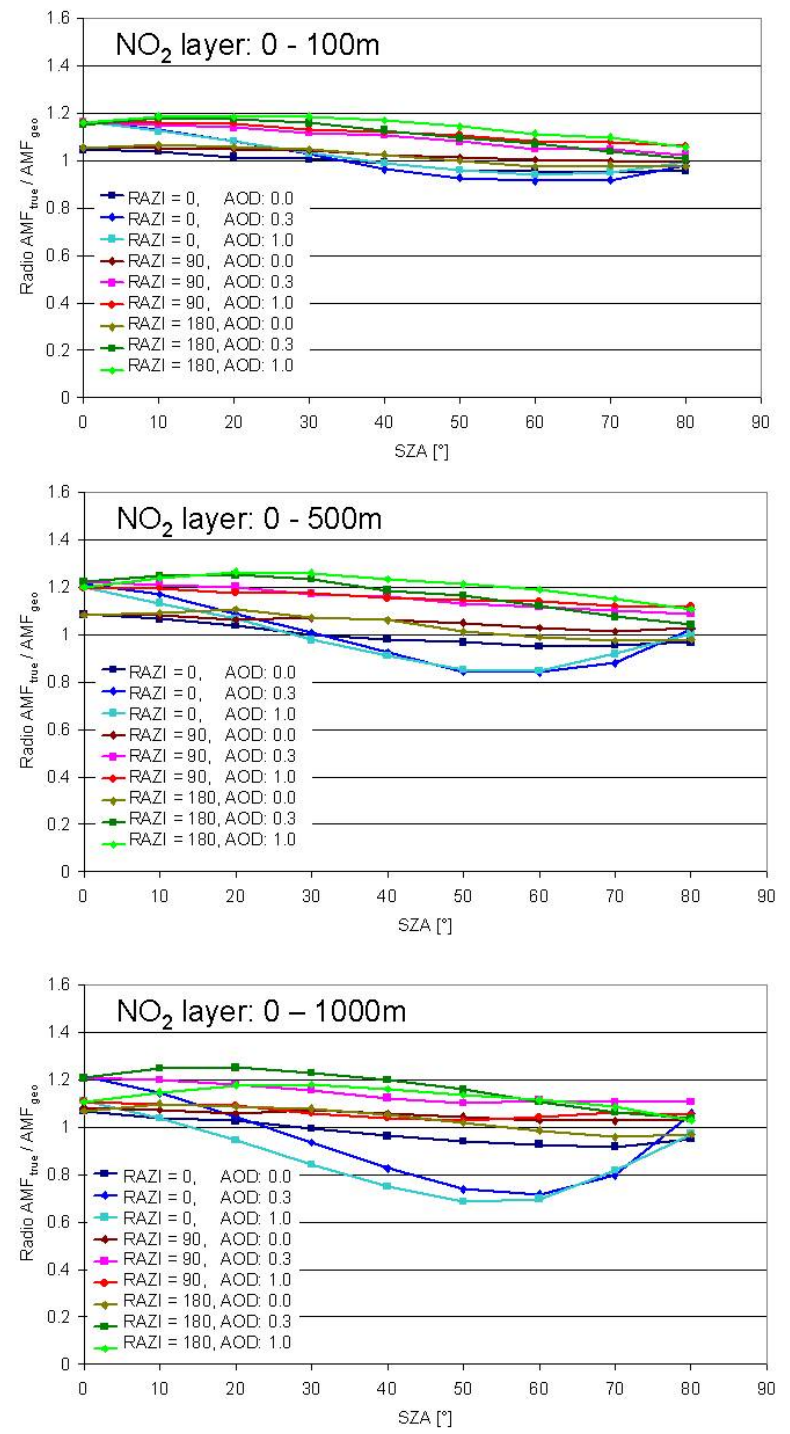

Fig. A3. Relative deviation of the true tropospheric VCDs (derived from radiative transfer simulations) from the geometric VCD for aerosol optical depth, aerosol layer heights and relative azimuth angles as a function of the solar zenith angle. Panels (a) to (c) show the results for different $\mathrm{NO}_{2}$ layer heights.

\section{Appendix B}

\section{Potential effects of localised emissions on the NO to $\mathrm{NO}_{2}$ ratio}

In the main part of the paper it was mentioned that for strong and localised $\mathrm{NO}_{\mathrm{x}}$ sources, like e.g. power plants, the atmospheric $\mathrm{NO}_{\mathrm{x}}$ mixing ratios close to the source might be higher than the $\mathrm{O}_{3}$ mixing ratios of the surrounding air. Since the NO to $\mathrm{NO}_{2}$ ratio depends on the ozone mixing ratio, in such cases less $\mathrm{NO}_{\mathrm{x}}$ will be converted to $\mathrm{NO}_{2}$ which eventually can be detected by our measure-
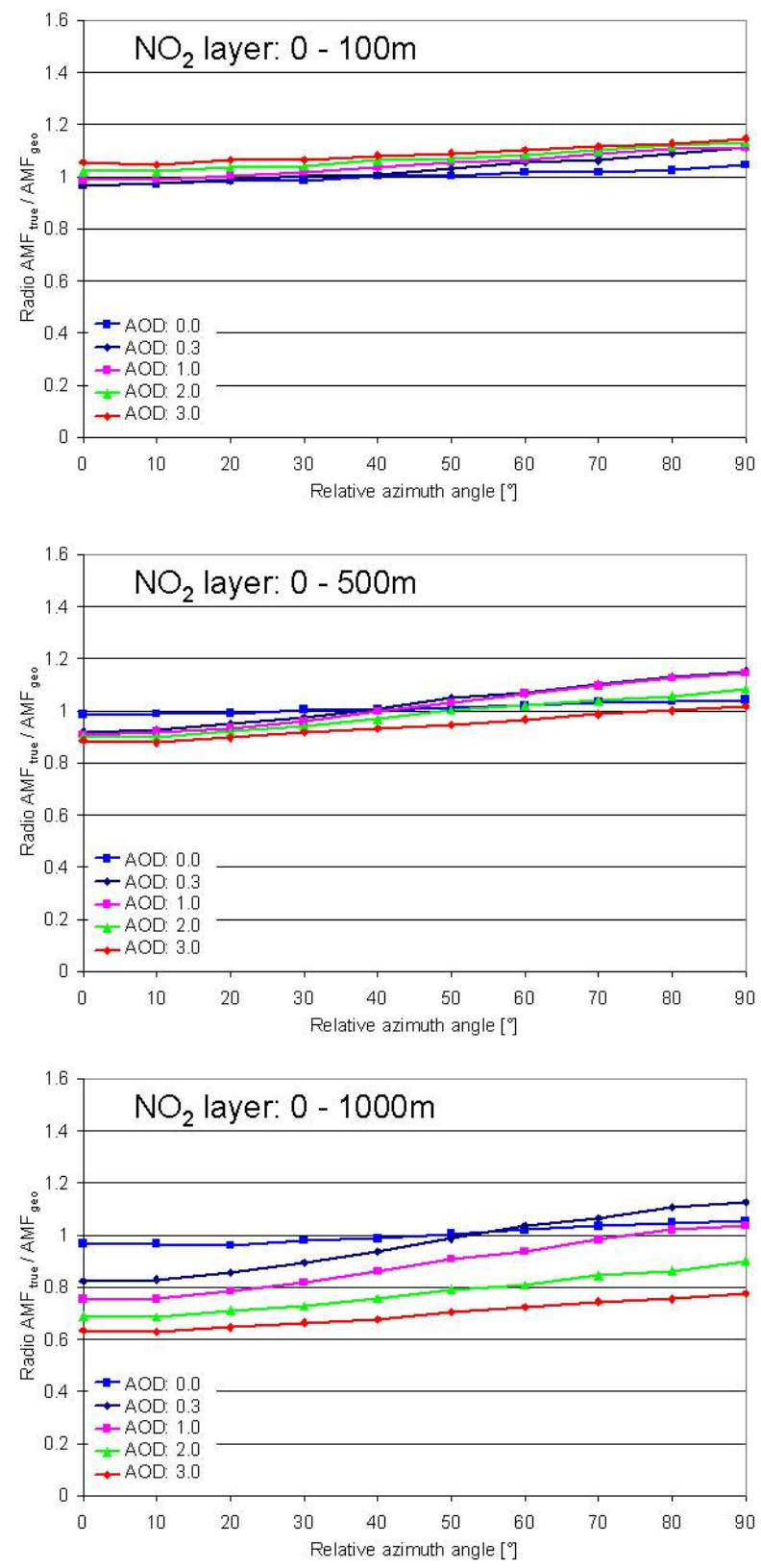

Fig. A4. Relative deviation of the true tropospheric VCDs (derived from radiative transfer simulations) from the geometric VCD for aerosol optical depth, aerosol layer heights and relative azimuth angles as a function of the relative azimuth angle. Panels (a) to (c) show the results for different $\mathrm{NO}_{2}$ layer heights.

ments. Here we estimate the $\mathrm{NO}_{\mathrm{x}}$ mixing ratios in the plumes from two fossil fuel power plants which are located within the surrounded area: Rajghat Power Station and Pragati Gas Power Station (see Fig. 1). The Rajghat Power Station is fired by Sub-bituminous coal and has a capacity of 135 MW. The Pragati Gas Power Station is fired by gas and has a capacity of $330 \mathrm{MW}$ (http://en.wikipedia.org/ 
wiki/List_of_power_stations_in_India). Using emission factors from the study by Gurjar et al. (2004), the $\mathrm{NO}_{\mathrm{x}}$ emissions from the Rajghat Power Station are estimated to about $0.5 \times 10^{24}$ molec $\mathrm{cm}^{-2} \mathrm{~s}^{-1}$ and from the Pragati Gas Power Station to about $1.2 \times 10^{24}$ molec $\mathrm{cm}^{-2} \mathrm{~s}^{-1}$.

On 13 and 14 April 2010 the distance from both power plants to the car MAXDOAS measurements is about $10 \mathrm{~km}$ and the wind speed is about $6 \mathrm{~m} \mathrm{~s}^{-1}$. On 15 April the distance from the power plants to the car MAXDOAS measurements is about $3 \mathrm{~km}$ and the wind speed is about $3 \mathrm{~m} \mathrm{~s}^{-1}$. On 15 January 2011 both power stations are outside of the driving circle. According to the solar irradiation and the wind speed the Pasquill-Turner stability classes (e.g. Seinfeld and Pandis, 2006) are C (slightly unstable) for 13 and 14 April 2010 and B (unstable) for 15 April 2010. Thus the plumes are strongly diluted before they were observed by the car MAXDOAS measurements. On 13 and 14 April the average $\mathrm{NO}_{\mathrm{x}}$ mixing ratios in the plumes of both power plants are reduced to values of about $20 \mathrm{ppb}$ and $8 \mathrm{ppb}$, respectively. On 15 April the average $\mathrm{NO}_{\mathrm{x}}$ mixing ratios in the plumes of both power plants are reduced to values of about $40 \mathrm{ppb}$ and $17 \mathrm{ppb}$, respectively.

During noon and afternoon $\mathrm{O}_{3}$ average mixing ratios in Delhi are typically in the range of $45 \mathrm{ppb}$ (Guttikunda, 2009). Thus on 13 and 14 April most of the emitted $\mathrm{NO}_{\mathrm{x}}$ is already converted to $\mathrm{NO}_{2}$ at the location of the car MAXDOAS measurements. On 15 April the conversion might be slightly reduced for the emissions from the Pragati Gas Power Station, because the $\mathrm{NO}_{\mathrm{x}}$ is of the same order as the $\mathrm{O}_{3}$ mixing ratios.

Acknowledgements. The research leading to these results has received funding from the European Union's Seventh Framework Programme FP/2007-2011 within the project "MEGAPOLI", grant agreement no. 212520. The authors are thankful for the help and support received from Ravi Singh, Vice-Chancellor and Sunil Mishra, Dean Research, Sharda University to carry out Car MAX-DOAS observations in Delhi and sponsoring visit of MS and AC to the Max Planck Institute for Chemistry. We acknowledge the free use of tropospheric $\mathrm{NO}_{2}$ column data from the OMI sensor from www.temis.nl. We acknowledge European Commission, Joint Research Centre (JRC)/Netherlands Environmental Assessment Agency (PBL) Emission Database for Global Atmospheric Research (EDGAR), release version 4.1. http://edgar. jrc.ec.europa.eu, 2010. Population density Grids are taken from the Center for International Earth Science Information Network (CIESIN), Columbia University; and Centro Internacional de Agricultura Tropical (CIAT). 2005. Gridded Population of the World Version 3 (GPWv3): Population Density Grids. Palisades, NY: Socioeconomic Data and Applications Center (SEDAC), Columbia University. Available at http://sedac.ciesin.columbia.edu/gpw (Balk and Yetman, 2004). ECMWF operational analysis data provided by ECMWF. For Radiance Night-time lights, we acknowledge Daniel Ziskin. Data processing by NOAA's National Geophysical Data Center. DMSP data collected by the US Air Force Weather Agency. We thank two anonymous reviewers for their very good suggestions.
The service charges for this open access publication have been covered by the Max Planck Society.

Edited by: M. Gauss

\section{References}

Babu, S. S., Moorthy, K. K., Manchanda, R. K., Sinha, P. R., Satheesh, S. K., Vajja, D. P., Srinivasan, S., and Kumar, V. H. A.: Free tropospheric black carbon aerosol measurements using high altitude balloon: Do BC layers build "their own homes" up in the atmosphere?, Geophys. Res. Lett., 38, L08803, doi:10.1029/2011GL046654, 2011.

Beirle, S., Boersma, K. F., Platt, U., Lawrence, M. G., and Wagner, T.:

Megacity emissions and lifetimes of nitrogen oxides probes from space, Science, 333, 1737-1739, doi:10.1126/science.1207824, 2011.

Balk, D. and Yetman, G.: The global distribution of population: evaluating the gains in resolution refinement, New York: Center for International Earth Science Information Network (CIESIN), Columbia University, 2004.

Bobrowski, N., Hönninger, G., Galle, B., and Platt, U.: Detection of bromine monoxide in a volcanic plume, Nature, 423, 273-276, 2003.

Boersma, K. F., Eskes, H. J., Veefkind, J. P., Brinksma, E. J., van der A, R. J., Sneep, M., van den Oord, G. H. J., Levelt, P. F., Stammes, P., Gleason, J. F., and Bucsela, E. J.: Near-real time retrieval of tropospheric $\mathrm{NO}_{2}$ from OMI, Atmos. Chem. Phys., 7, 2103-2118, doi:10.5194/acp-7-2103-2007, 2007.

Boersma, K. F., Eskes, H. J., Dirksen, R. J., van der A, R. J., Veefkind, J. P., Stammes, P., Huijnen, V., Kleipool, Q. L., Sneep, M., Claas, J., Leitão, J., Richter, A., Zhou, Y., and Brunner, D.: An improved tropospheric $\mathrm{NO}_{2}$ column retrieval algorithm for the Ozone Monitoring Instrument, Atmos. Meas. Tech., 4, 19051928, doi:10.5194/amt-4-1905-2011, 2011.

Bogumil, K., Orphal, J., Homann, T., Voigt, S., Spietz, P., Fleischmann, OC, Vogel, A., Hartmann, M., Kromminga, H., Bovensmann, H., Frerik, J., and Burrows, J. P.: Measurements of Molecular Absorption Spectra with the SCIAMACHY PreFlight Model: Instrument Characterization and Reference Data for Atmospheric Remote-Sensing in the 230-2380 nm Region, J. Photochem. Photobiol. A., 157, 167-184, 2003.

Brinksma, E. J., Pinardi, G., Volten, H., Braak, R., Richter, A., Schönhardt, A.,Van Roozendael, M., Fayt, C., Hermans, C., Dirksen, RJ., Vlemmix, T., Berkhout, A. J. C., Swart, D. P. J., Ötjen, H., Wittrock, F., Wagner, T., Ibrahim, O. W., de Leeuw, G., Moerman, M., Curier, R. L., Celarier, E. A., Knap, W. H., Veefkind, J. P., Eskes, H. J., Allaart, M., Rothe, R., Piters, A. J. M., and Levelt, P. F.: The 2005 and 2006 DANDELIONS $\mathrm{NO}_{2}$ and Aerosol Validation Campaigns, J. Geophys. Res., 113, D16S46, doi:10.1029/2007JD008808, 2008.

Cantrell, C. A.: Technical Note: Review of methods for linear leastsquares fitting of data and application to atmospheric chemistry problems, Atmos. Chem. Phys., 8, 5477-5487, doi:10.5194/acp8-5477-2008, 2008

Chen, D., Zhou, B., Beirle, S., Chen, L. M., and Wagner, T.: Tropospheric $\mathrm{NO}_{2}$ column densities deduced from zenith-sky DOAS measurements in Shanghai, China, and their applica- 
tion to satellite validation, Atmos. Chem. Phys., 9, 3641-3662, doi:10.5194/acp-9-3641-2009, 2009.

Celarier, E. A., Brinksma, E. J., Gleason, J. F., Veefkind, J. P., Cede, A., Herman, J. R., Ionov, D., Goutail, F., Pommereau, J.P., Lambert, J.-C., van Roozendael, M., Pinardi, G., Wittrock, F., Schönhardt, A., Richter, A., Ibrahim, O. W., Wagner, T., Bojkov, B., Mount, G., Spinei, E., Chen, C. M., Pongetti, T. J., Sander, S. P., Bucsela, E. J., Wenig, M. O., Swart, D. P. J., Volten, H., Kroon, M., and Levelt, P. F.: Validation of Ozone Monitoring Instrument nitrogen dioxide columns, J. Geophys. Res., 113, D15S15, doi:10.1029/2007JD008908, 2008.

Deutschmann, T., Beirle, S., Frieß, U., Grzegorski, M., Kern, C., Kritten, L., Platt, U., Pukite, J., Wagner, T., Werner, B., and Pfeilsticker, K.: The Monte Carlo Atmospheric Radiative Transfer Model McArtim: Introduction and Validation of Jacobians and 3D Features, J. Quant. Spectrosc. Ra., 112, 1119-1137, doi:10.1016/j.jqsrt.2010.12.009, 2011.

Dubovik, O., Holben, B. N., Eck, T. F., Smirnov, A., Kaufman, Y. J., King, M. D., Tanre', D., and Slutsker, I.: Variability of absorption and optical properties of key aerosol types observed in worldwide locations, J. Atmos. Sci. 59, 590-608, 2002.

Elsayed, N. M.: Toxicity of nitrogen dioxide: an introduction, Toxicology, 89, 161-174, 1994.

European Commission, Joint Research Centre (JRC)/Netherlands Environmental Assessment Agency (PBL).: Emission Database for Global Atmospheric Research (EDGAR), release version 4.1, http://edgar.jrc.ec.europa.eu, 2010

Fayt, C. and Van Roozendael, M.: WinDOAS 2.1 Software User Manual, (http://www.oma.be/BIRA-IASB/Molecules/BrO/ WinDOAS-SUM-210b.pdf), 2001.

Gautam, R., Hsu, N. C., Kafatos, M., and Tsay. S.-C.: Influences of winter haze on fog/low cloud over the Indo-Gangetic plains, J. Geophys. Res., 112, D05207, doi:10.1029/2005JD007036, 2007.

Goyal, S. K., Ghatge, S. V., Nema, P., and Tamhane, S. M.: Understanding urban vehicular pollution problem vis-à-vis ambient air quality - case study of a megacity (Delhi, India), Environ. Monit. Assess., 119, 557-569, doi:10.1007/s10661-005-9043-2, 2006.

Gurjar, B. R., Aardenne, J. A., van, Lelieveld, J., and Mohan, M.: Emission estimates and trends (1990-2000) for megacity Delhi and implications, Atmos. Environ., 38, 5663-5681, 2004.

Guttikunda, S.: Photochemistry of Air Pollution in Delhi, India: A Monitoring Based Analysis, Simple Interactive Models for better air quality (SIM-air) Working Paper Series 25-2009, http://urbanemissions.info/sim-series-25.html, 2009.

Hains, J. C., Boersma, K. F., Kroon, M., Dirksen, R. J., Cohen, R. C., Perring, A. E., Bucsela, E., Volten, H., Swart, D. P. J., Richter, A., Wittrock, F., Schoenhardt, A., Wagner, T., Ibrahim, O. W., van Roozendael, M., Pinardi, G., Gleason, J. F., Veefkind, J. P., and Levelt, P.: Testing and improving OMI DOMINO tropospheric $\mathrm{NO}_{2}$ using observations from the DANDELIONS and INTEX B validation campaigns, J. Geophys. Res., 115, D05301, doi:10.1029/2009JD012399, 2010.

Heckel, A., Kim, S.-W., Frost, G. J., Richter, A., Trainer, M., and Burrows, J. P.: Influence of low spatial resolution a priori data on tropospheric $\mathrm{NO}_{2}$ satellite retrievals, Atmos. Meas. Tech., 4, 1805-1820, doi:10.5194/amt-4-1805-2011, 2011.

Heland, J., Schlager, H., Richter, A., and Burrows, J. P.: First comparison of tropospheric NO2 column densities retrieved from GOME measurements and in situ aircraft profile measurements,
Geophys. Res. Lett., 29, 1983, doi:10.1029/2002GL015528, 2002.

Hermans, C., Vandaele, A. C., Carleer, M., Fally, S., Colin, R., Jenouvrier, A., Coquart, B., and Mérienne, M.-F.: Absorption Cross-Sections of Atmospheric Constituents, $\mathrm{NO}_{2}, \mathrm{O}_{2}$, and $\mathrm{H}_{2} \mathrm{O}$, Environ. Sci. Pollut. Res., 6, 151-158, 1999.

Hönninger G. and Platt U.: Observations of $\mathrm{BrO}$ and its vertical distribution during surface ozone depletion at Alert, Atmos. Environ., 36, 2481-2490, 2002.

Ibrahim, O., Shaiganfar, R., Sinreich, R., Stein, T., Platt, U., and Wagner, T.: Car MAX-DOAS measurements around entire cities: quantification of $\mathrm{NO}_{\mathrm{x}}$ emissions from the cities of Mannheim and Ludwigshafen (Germany), Atmos. Meas. Tech., 3, 709-721, doi:10.5194/amt-3-709-2010, 2010.

Jacob, D. J.: Introduction to Atmospheric Chemistry, Princeton University Press, 1999.

Johansson, M., Galle, B., Yu, T., Tang, L., Chen, D., Li, H., Li, J. X., and Zhang, Y.: Quantification of total emission of air pollutants from Beijing using mobile mini-DOAS, Atmos. Environ., 42, 6926-6933, 2008.

Johansson, M., Rivera, C., de Foy, B., Lei, W., Song, J., Zhang, Y., Galle, B., and Molina, L.: Mobile mini-DOAS measurement of the outflow of $\mathrm{NO}_{2}$ and $\mathrm{HCHO}$ from Mexico City, Atmos. Chem. Phys., 9, 5647-5653, doi:10.5194/acp-9-5647-2009, 2009.

Kraus, S.: DOASIS, A Framework Design for DOAS, PhDthesis, University of Mannheim (http://hci.iwr.uni-heidelberg.de/ publications/dip/2006/Kraus_PhD2006.pdf), 2006.

Kurucz, R. L., Furenlid, I., Brault, J., and Testerman, L.: Solar flux atlas from $296 \mathrm{~nm}$ to $1300 \mathrm{~nm}$, National Solar Observatory Atlas No. 1, Office of University publisher, Harvard University, Cambridge, 1984.

Lal, S.: Trace gases over the Indian region, Indian Journal of Radio and Space Physics, 36, 556-579, 2007.

Leue, C., Wenig, M., Wagner, T., Klimm, O., Platt, U., and Jähne, B.: Quantitative analysis of NOx emissions from Global Ozone Monitoring Experiment satellite image sequences, J. Geophys. Res., 106, 5493-5505, 2001.

Levelt, P. F. and Noordhoek, R.: OMI Algorithm Theoretical Basis Document Volume I: OMI Instrument, Level 0-1b Processor, Calibration \& Operations, Tech. Rep. ATBD-OMI-01, Version $1.1,2002$.

Martin, R. V., Jacob, D. J., Chance, K., Kurosu, T. P., Palmer, P. I., and Evans, M. J.: Global inventory of nitrogen oxide emissions constrained by space-based observations of $\mathrm{NO}_{2}$ columns, J. Geophys. Res., 108, 4537, doi:10.1029/2003JD003453, 2003.

Olivier, J. G. J., Bouwman, A. F., Van der Hoek, K. W., and Berdowski, J. J. M.: Global air emission inventories for anthropogenic sources of $\mathrm{NO}_{\mathrm{x}}, \mathrm{NH}_{3}$ and $\mathrm{N}_{2} \mathrm{O}$ in 1990, Environ. Pollut. 102, 135-148, 1998.

Piters, A. J. M., Boersma, K. F., Kroon, M., Hains, J. C., Van Roozendael, M., Wittrock, F., Abuhassan, N., Adams, C., Akrami, M., Allaart, M. A. F., Apituley, A., Bergwerff, J. B., Berkhout, A. J. C., Brunner, D., Cede, A., Chong, J., Clémer, K., Fayt, C., Frieß, U., Gast, L. F. L., Gil-Ojeda, M., Goutail, F., Graves, R., Griesfeller, A., Großmann, K., Hemerijckx, G., Hendrick, F., Henzing, B., Herman, J., Hermans, C., Hoexum, M., van der Hoff, G. R., Irie, H., Johnston, P. V., Kanaya, Y., Kim, Y. J., Klein Baltink, H., Kreher, K., de Leeuw, G., Leigh, R., Merlaud, A., Moerman, M. M., Monks, P. S., Mount, G. H., Navarro- 
Comas, M., Oetjen, H., Pazmino, A., Perez-Camacho, M., Peters, E., du Piesanie, A., Pinardi, G., Puentadura, O., Richter, A., Roscoe, H. K., Schönhardt, A., Schwarzenbach, B., Shaiganfar, R., Sluis, W., Spinei, E., Stolk, A. P., Strong, K., Swart, D. P. J., Takashima, H., Vlemmix, T., Vrekoussis, M., Wagner, T., Whyte, C., Wilson, K. M., Yela, M., Yilmaz, S., Zieger, P., and Zhou, Y.: The Cabauw Intercomparison campaign for Nitrogen Dioxide measuring Instruments (CINDI): design, execution, and early results, Atmos. Meas. Tech. Discuss., 4, 5935-6005, doi:10.5194/amtd-4-5935-2011, 2011.

Platt, U. and Stutz, J.: Differential Optical Absorption Spectroscopy, Principles and Applications, Springer, Berlin, 2008.

Ramanathan, V. and Ramana, M. V.: Persistent, Widespread and Strongly Absorbing Haze over the Himalayan Foothills and the Indo-Ganges Plains, Pure Appl. Geophys., 162, 1609-1626, doi:10.1007/s00024-005-2685-8, 2005.

Ramanathan, V., Chung, C., Kim, D., Bettge, T., Buja, L., Kiehl, J. T., Washington, W. M., Fu, Q., Sikka, D. R., and Wild, M.: Atmospheric brown clouds: Impacts on South Asian climate and hydrological cycle, P. Natl. Acad. Sci. USA, 102, 5326-5333, 2005.

Ravishankara, R., Liu, S., Platt, U., Bates, T., Bey, I., Carslaw, K., Chipperfield, M., Douglass, A., Fahey, D., Feingold, G., Fuzzi, S., Gettleman, A., Granier, C., Hauglustine, D., Mari, C., O’Neill, A., Parrish, D., Quinn, P., Randel, W., Rosenlof, K., Shepherd, T., and Simon, P.: Climate Chemistry Interactions, Report from the joint SPARC/IGAC workshop, 3-5 April 2003, Giens, France, http://www.atmosp.physics.utoronto.ca/SPARC/ RelatedPublications/IGAC_SPARC_FINAL.pdf, 2004.

Rehman, I. H., Ahmed, T., Praveen, P. S., Kar, A., and Ramanathan, V.: Black carbon emissions from biomass and fossil fuels in rural India, Atmos. Chem. Phys., 11, 7289-7299, doi:10.5194/acp-117289-2011, 2011.

Rivera, C., Sosa, G., Whrnschimmel, H., de Foy, B., Johansson, M., and Galle, B.: Tula industrial complex (Mexico) emissions of $\mathrm{SO}_{2}$ and $\mathrm{NO}_{2}$ during the MCMA 2006 field campaign using a mobile mini-DOAS system, Atmos. Chem. Phys., 9, 6351-6361, doi:10.5194/acp-9-6351-2009, 2009.

Rothman, L. S., Jacquemart, D., Barbe, A., Benner, D. C., Birk, M., Brown, L. R., Carleer, M. R., Chackerian Jr., C., Chance, K., Coudert, L. H., Dana, V., Devi, V. M., Flaud, J.-M. , Gamache, R. R., Goldman, A., Hartmann, J.-M., Jucks, K. W., Maki, A. G., Mandin, J.-Y., Massie, S. T., Orphal, J., Perrin, A., Rinsland, C. P., Smith, M. A. H., Tennyson, J., Tolchenov, R. N., Toth, R. A., Vander Auwera, J., Varanasi, P., and Wagner, G.: The HITRAN 2004 molecular spectroscopic database, J. Quant. Spectrosc. Ra., 96 139-204, 2005.

Satheesh, S. K., Vinoj V., and Moorthy K. K.: Weekly periodicities of aerosol properties observed at an urban location in India, Atmos. Res., 101, 307-313, doi:10.1016/j.atmosres.2011.03.003, 2011.

Seinfeld, J. H. and Pandis, S. N.: From air pollution to climate change. Atmospheric Chemistry and Physics, John Wiley \& Sons, New York 2nd edition, 2006.

Singh R. P., Dey, S., Tripathi, S. N., Tare, V., and Holben, B.: Variability of aerosol parameters over Kanpur, northern India, J. Geophys. Res., 109, D23206, doi:10.1029/2004JD004966, 2004.

Singh, R. P., Prasad, A. K., Chauhan, S. S. S., and Singh, S.: Impact of growing urbanization and air pollution on the regional climate over India, International Association for Urban Climate Newsletter, Issue No. 14, December 2005, 5-10, 2005.

Sluis, W. W., Allaart, M. A. F., Piters, A. J. M., and Gast, L. F. L.: The development of a nitrogen dioxide sonde, Atmos. Meas. Tech., 3, 1753-1762, doi:10.5194/amt-3-1753-2010, 2010.

Solomon, S., Schmeltekopf, A. L., and Sanders, R. W.: On the interpretation of zenith sky absorption measurements, J. Geophys. Res., 92, 8311-8319, doi:10.1029/JD092iD07p08311, 1987.

Spicer, C. W.: Nitrogen Oxide Reactions in the Urban Plume of Boston, Science, 215, 1095-1097, 1982.

Vandaele, A. C., Hermans, C., Simon, P. C., Roozendael, M., Guilmot, J. M., Carleer, M., and Colin, R.: Fourier transform measurement of $\mathrm{NO}_{2}$ absorption cross-section in the visible range at room temperature, J. Atmos. Chem., 25, 289-305, 1996.

Van Roozendael, M., Fayt, C., Post, P., Hermans, C., and Lambert, J.-C.: Retrieval of $\mathrm{BrO}$ and $\mathrm{NO}_{2}$ from UV-Visible Observations, in: Sounding the troposphere from space: a new era for atmospheric chemistry, edited by: Borell, P., Borrell, P. M., Burrows, J. P., and Platt, U., Springer, Heidelberg, ISBN 3-540-40873-8, 2004.

Volkamer, R., Spietz, P., Burrows, J., and Platt, U.: High-resolution absorption cross-section of glyoxal in the UV-vis and IR spectral ranges, J. Photochem. Photobiol. A, 172, 35-46, 2005.

Volkamer, R., Kurosu, T. P., Chance, K., Li, Z., Zhang, Y., Brauers, T., and Wahner, A.: Spatial Variability of Glyoxal, HCHO and $\mathrm{NO}_{2}$ during PRD-2006: Comparison of mobile Mini-MAXDOAS and OMI satellite data in the Pearl River Delta, China, Eos Trans. AGU, 87, (52), Fall Meet. Suppl., Abstract A31B0897, 2006.

Wagner, T., Dix, B., Friedeburg, C. v., Frieß, U., Sanghavi, S., Sinreich, R., and Platt, U.: MAX-DOAS $\mathrm{O}_{4}$ measurements a new technique to derive information on atmospheric aerosols. (I) Principles and information content, J. Geophys. Res., 109, D22205, doi:10.1029/2004JD004904, 2004.

Wagner, T., Ibrahim, O., Shaiganfar, R., and Platt, U.: Mobile MAX-DOAS observations of tropospheric trace gases, Atmos. Meas. Tech., 3, 129-140, doi:10.5194/amt-3-129-2010, 2010.

Wagner, T., Beirle, S., Brauers, T., Deutschmann, T., Frieß, U., Hak, C., Halla, J. D., Heue, K. P., Junkermann, W., Li, X., Platt, U., and Pundt-Gruber, I.: Inversion of tropospheric profiles of aerosol extinction and $\mathrm{HCHO}$ and $\mathrm{NO}_{2}$ mixing ratios from MAX-DOAS observations in Milano during the summer of 2003 and comparison with independent data sets, Atmos. Meas. Tech. Discuss., 4, 3891-3964, doi:10.5194/amtd-4-3891-2011, 2011.

Wittrock, F., Oetjen, H., Richter, A., Fietkau, S., Medeke, T., Rozanov, A., and Burrows, J. P.: MAX-DOAS measurements of atmospheric trace gases in Ny-Ålesund - Radiative transfer studies and their application, Atmos. Chem. Phys., 4, 955-966, doi:10.5194/acp-4-955-2004, 2004.

World Health Organization, Health Aspects of Air. Pollution with Particulate Matter, Ozone and Nitrogen Dioxide. Report on a WHO Working Group, 13-15 January 2003, Bonn, Germany, 2003.

Ziskin, D., Kimberly, B., Feng, C. H., Tilottama, G., and Chris, E.: Methods Used For the 2006 Radiance Lights, Proceedings of the 30th Asia-Pacific Advanced Network Meeting, 131-142, http://www.ngdc.noaa.gov/dmsp/download_radcal.html, 2010. 